\title{
Appointing and Remunerating Insolvency Practitioners in Japan: The Roles of Japanese Courts
}

\author{
Stacey Steele*
}

\begin{abstract}
Japanese courts play an important role in appointing and remunerating insolvency practitioners. This article examines the roles of courts based on academic and practitioner literature, judicial decisions and interviews with practitioners and former and current judicial officers. First, the article focuses on the methods used to appoint practitioners and the evolution of the system at the Tokyo District Court, Japan's busiest insolvency jurisdiction. Secondly, the article examines the courts' roles in reviewing and setting practitioners' remuneration through another case study from the Tokyo District Court. Practices trialled and developed in Tokyo are often adapted for local purposes around Japan. The article argues that the courts' involvement has helped to keep the cost of resolving insolvency in Japan down by global standards. The review and setting of remuneration deserves particular attention with the increasing prevalence of pre-packaged and informal restructuring that prima facie appears to allow for greater freedom to set remuneration as between the practitioner and debtor-client, and may lead to higher fees. The article uses a case study to demonstrate that pre-packaged restructuring is still influenced by the court, however, arguing that the relationship between the court and practitioners remains important. Finally, the article suggests that changes in Japanese insolvency practice and external factors may require the courts and the profession to revisit approaches to appointing and remunerating practitioners.
\end{abstract}

\section{Introduction: Japanese courts' roles in appointing and setting the remuneration of insolvency practitioners}

This article examines the courts' roles in appointing and setting the remuneration of insolvency practitioners in Japan based on an analysis of Japanese insolvency legislation, academic and practitioner literature, judicial decisions and interviews with practitioners and former and current judicial officers. This article does not consider disciplinary mechanisms for court-appointed insolvency practitioners, although the issues of misconduct and remuneration are sometimes

\footnotetext{
* Associate Professor and Associate Director (Japan), Asian Law Centre, Melbourne Law School. E-mail: <s.steele@unimelb.edu.au>. The author would like to thank Reegan Grayson-Morison, Principal Research Assistant, Asian Law Centre, for her assistance with interviews in Japan and research, Ms Emiko Morisato (Esq.) for her assistance with research in relation to the regulation and disciplining of insolvency practitioners in Japan, Ms Kaori Kano, Principal Research Assistant, Asian Law Centre, for her research assistance and project management, and Mr Naoya Mori, Japaneasy for his assistance with understanding Japanese materials.
}

This is the author manuscript accepted for publication and has undergone full peer review but has not been through the copyediting, typesetting, pagination and proofreading process, which may lead to differences between this version and the Version of Record. Please cite this article as doi: 10.1002/iir.1270 
linked. ${ }^{1}$ Research in Japanese found few cases where misconduct by insolvency practitioners has been formally reported or prosecuted. ${ }^{2}$ Even where there has been disciplinary action against bengoshi (licensed attorney) who act as insolvency practitioners, including due to objections to remuneration, the number of reported cases is small especially when compared to the number of insolvency filings. ${ }^{3}$ The article argues that court involvement in appointing and remunerating insolvency practitioners in Japan has contributed to this situation where there are few formal complaints against insolvency practitioners. ${ }^{4}$ Further, whilst court involvement in reviewing and

\footnotetext{
${ }^{1}$ Insolvency practitioners also act in the shadow of the courts' and other supervisory bodies' disciplinary powers. In the Australian context, see Stacey Steele, Vivien Chen and Ian Ramsay, 'An Empirical Study of Australian Judicial Decisions relating to Insolvency Practitioner Remuneration’ (2016) 24 Insolv LJ 165-191.

${ }^{2}$ There are various articles dedicated to the trustee's duty of reasonable care of a good manager (zenkan chüi gimu), however. See, for example: (1) Yasuyuki Nakai, 'Hasan kanzai nin no zenkan chūi gimu' (Bankruptcy Trustee's Duty of Reasonable Care of a Good Manager) (2007) 1811 Kinyū hōmu jijō (Financial Law Journal) 40. Nakai offers a bengoshi perspective on two Supreme Court of Japan cases dealing with the duty; (2) Makoto Ito, 'Hasan kanzai nin no shokumu saikō' (Re-examining a Bankruptcy Trustee's Professional Duties) (2005) 1183 Hanrei Taimuzu (Hanrei Times) 35-46; (3) Makoto Ito et al., 'Hasan kanzai nin no zenkan chūi gimu - 'rigai kankei'nin' gainen no paradaimu shifuto' (A Bankruptcy Trustee's Duty of Reasonable Care of a Good Manager: The Paradigm Shift to the Notion of 'Interested Parties') (2011) 1930 Kinyū hōmu jijōo (Financial Law Journal) 64-75; (4) Ichiro Nagaishi, 'Hasan kanzai nin to CSR' (Relationship between Bankruptcy Trustee and CSR) (2005) 4(2) The Hitotsubashi Journal of Law and International Studies 337. Nagaishi discusses a bankruptcy trustee's responsibility to society, particularly for environmental issues, in relation to property monetized as part of the trustee's role; (5) Takeshi Yasuki, 'Tōsan shori jitsumu to bengoshi no rieki sōhan' (Insolvency Procedure Practice and Bengoshi Conflict of Interest) in Mitsumasa Tanabe (ed), Imanaka Toshiaki Sensei koki kinen: saishin tōsanhō kaishahō wo meguru jitsumu jō no mondai (Problems occurring in the Practice of Contemporary Bankruptcy Law and Corporate Law - Memorial Publication on the Seventieth Birthday of Professor Toshiaki Imanaka) (Minjihō Kenkyūkai, Tokyo, 2005) 506-525.

${ }^{3}$ Sato discusses some cases where the trustee sued the mōshitate dairi'nin (petitioning representative) for overcharging fees. See Tetsuo Sato, 'Kanzai nin seido ni miru nichi doku chū no hikaku' (A Comparison of Japan, Germany and China through their Trustee Systems) (2014) 1988 Kinyū hōmu jijō (Financial Law Journal) 50, 60; and Tetsuo Sato, 'Mushō kōi hi’nin to sagai kōi hi’nin no kankei: dairi'nin no hōshū hi'nin jiken kara kangaeru' (Relationship between Denial of Gratuitous Act and Denial of Fraudulent Act: From the Perspective of Denial of a Representative's Remuneration) in Saiguchi Chiharu Bengoshi (Moto Saikōsai Hanji) Kiju kinen 'Tōsan no jissen' (Insolvency Practice: Memorial Publication on the Seventy Seventh Birthday of Chiharu Saiguchi Esq. (former High Court Judge)) (Yuhikaku, Tokyo, 2016) 261, 266-269. See also Bengoshi chōkai shobun kensaku sentā (Lawyer Disciplinary Measure Search Centre) website at: <http://shyster.sakura.ne.jp/>. Bengoshi chōkai shobun kensaku sentā was created by Bengoshi jichi wo kangaeru kai (Committee to consider the self-regulation of bengoshi) and provides information on disciplinary actions against bengoshi collected from the official gazette and Jiy $\bar{u}$ to seigi, the official journal of the Japan Federation of Bar Associations. It enables users to search for bengoshi who have been disciplined by entering either the name of the bengoshi, bengoshi number, affiliated bar association, firm name, or year or the type of discipline received. The search engine is of limited use for the purposes of this article given the detailed personal information required to search for a disciplined bengoshi. A search cannot be made by matter type such as 'bankruptcy'.

${ }^{4}$ Other explanations include, for example, reluctance of creditors to challenge (cultural reasons), lack of avenues to challenge (institutional reasons) or the cost involved (economic reasons). Further, where there has been misconduct, it may not have been made public and judges simply avoid appointing those people to future matters as discussed below. This approach may be counter-productive if there is a greater reliance on pre-petition insolvency
} 
setting remuneration does not necessarily lead to cheaper costs for private parties globally, the case studies analysed in this article support the view that court involvement has kept costs down in Japan. The case studies are drawn from the key formal insolvency proceedings in Japan and encompass the key categories of insolvency practitioners: bankruptcy and corporate reorganisation trustees (kanzai nin) and civil rehabilitation supervisors (kantoku i'in). In the vast majority of cases in Japan, a bengoshi performs these roles. Foreign lawyers are not qualified to act in these roles domestically; although they may become involved to the extent a cross-border matter has a Japanese connection. ${ }^{5}$

Although Japan is not unique in its preference for a high degree of court intervention in proceedings and practitioner supervision, this situation has implications for its approach to new developments in the jurisdiction such as the emergence of pre-petition practitioners who are not appointed by the courts and increasing numbers of informal workouts. Despite the Japanese courts' important role in insolvency proceedings there are few publications dedicated to critiquing the relationship between courts and insolvency practitioners in Japan. ${ }^{6}$

Research for this article also involved interviewing four bengoshi with extensive experience in Tokyo, three with more than 30 years' experience and one with ten years' experience. ${ }^{7}$ One

practitioners as people are unaware of what the courts know. Alternatively, the fact that a practitioner is not receiving any court appointments may put more sophisticated consumers on notice that something is amiss. See the discussion below in relation to appointments also.

${ }^{5}$ Japan has adopted a modified version of the UNCITRAL Model Law. See Gaikoku tōsan shori tetsuzuki no shōnin enjo ni kansuru hōritsu (Act on Recognition of and Assistance for Foreign Insolvency Proceedings, Act No 129, 2000). See also Steele and Chun, CCH 19-510 to 15-535 on cross-border proceedings in Japan generally. For an example of co-operation and co-ordination amongst Japanese and non-Japanese insolvency practitioners, see the Spansion Japan case. Spansion was a wholly-owned subsidiary of an American firm in the semiconductor manufacturing industry in Hideyuki Sakai, 'Jigyō saisei tetsuzuki no tenkai to shōraizō' (Development and the Future of Business Reorganisation Proceedings) in Hideki Matsushima et al. (eds), Atarashii jidai no minji shihō (Civil Justice in a New Era) (Shōji hōmu, Tokyo, 2011) 3, and English translation of this article, Hideyuki Sakai et al., 'A Revolution in Japanese Business Restructuring Proceedings: An Insolvency Practitioner's Perspective of the Early 21st Century and Future of Japanese Insolvency Law' (2017) American Bankruptcy Law Journal (forthcoming).

${ }^{6}$ See, Sato, 'Kanzai nin seido ni miru nichi doku chū no hikaku' (n 3); Mutsuo Tahara, 'Seiriya no jidai to bengoshi no tōsan jitsumu - jigyō saisei ni katsuyaku suru bengoshi no ishizue no tame ni' (Restructuring Era and Bengoshi Insolvency Practice: For the Sake of the Cornerstone of Bengoshi practising Company Restructuring) in Makoto Ito et al. (eds), Jidai wo riido suru saisei ron (Debates on Rehabilitation which lead the Era) (Shōji hōmu, Tokyo, 2013) 270-298. Tahara provides a history of the Japanese trustee system and discusses its current state. Tahara was a Supreme Court of Japan justice (2006-2013) and member of the Insolvency Law Committee of the Legislative Council in 1996; and Tetsuo Sato, 'Tōsan tetsuzuki ni okeru kikan no saikōsei' (Reconfiguration of Institutions involved in Insolvency Procedures) (1997) 1111 Jurisuto (Jurist) 187. For a recent critique, see Sato, 'Mushō kōi hi'nin to sagai kōi hi'nin no kankei: dairi'nin no hōshū hi'nin jiken kara kangaeru' (n 3). In English, see, for example, Jin Chun and Yuri Ide, 'DIP and the Trustee in Restructuring Proceedings: The Trend in Japan and Indications for the Future in China' (2011) 8(6) International Corporate Rescue 399-403.

${ }^{7}$ Informants gave informed written consent to be interviewed, according to Human Research Ethics Clearance. Project title: 'Japanese insolvency law: relationships between the courts and insolvency practitioners' (HREC 
judge and one court clerk with about 15 years' experience each who were based in the metropolitan area around Tokyo at the time were also interviewed. Further interviews and correspondence were also conducted with leading insolvency law specialists Dr Shinjiro Takagi and Takashi Sonoo Esq. Takagi is a former judge, bengoshi and insolvency practitioner. He is also Honorary Chair of the Japan Federation of Insolvency Professionals (INSOL Japan). Sonoo is a former judge who has written extensively about practice in relation to insolvency proceedings. ${ }^{8}$ He has also shared his personal experience in overseeing reforms to court practice at the Tokyo District Court in relation to insolvency law cases in his capacity as a Chief Judge and Head of the Bankruptcy and Restructuring Division when Japan's new civil rehabilitation procedure became effective in $2000 .{ }^{9}$ The findings from the research and interviews provide important insights into the development of a contemporary insolvency practitioner profession in Japan and the inter-related and evolving roles of courts.

The article begins by providing an overview of the modernization of Japanese insolvency law during the decade to 2005 and the law as it relates to the appointment and remuneration of insolvency practitioners. Insolvency law is now just another business strategy in Japan and insolvency practice is increasingly sophisticated. Secondly, this article examines contemporary developments in the process for appointing insolvency practitioners in bankruptcy and corporate reorganization proceedings in Japan, because this process plays a key role in the courts' ability to supervise and influence practitioners. Thirdly, this article analyses the courts' role in setting and reviewing the remuneration of court-appointed practitioners. This section analyses the factors a court considers when setting remuneration and uses a case study involving the development of lower, scheduled fees in asset-less and small-scale insolvencies as an example of court influence over fees. ${ }^{10}$

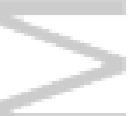

1442091). Interviewees were sourced through introductions from the author's contacts in the legal profession in Japan. Interviews were conducted by Reegan Grayson-Morison, Principal Research Assistant in Japan in November and December 2014, and the author in Melbourne in 2015. For other English-language examples of research using data from interviews with insolvency judges, see, Xianchu Zhang and Charles Booth, 'Chinese Bankruptcy Law in an Emerging Market Economy: The Shenzhen Experience' (2001) 15(1) Columbia Journal of Asian Law 1-32; and Zinian Zhang and Roman Tomasic, 'Corporate Reorganisation Reform in China: Findings from an Empirical Study in Zhejiang' (2016) 11(1) Asian Journal of Comparative Law 55-85.

${ }^{8}$ E.g., Takashi Sonoo et al., Jitusmu kaisetsu ichimon ittō minji saisei hō (Civil Rehabilitation Act: Practice and Interpretation Q\&A) (Seirin Shoin, Tokyo, 2011).

${ }^{9}$ Takashi Sonoo, 'Nihon ni okeru kigyō tōsan kankei hō no jijō to mondai ten' (The Actual Situation and Problems for Laws relating to Corporate Insolvency in Japan) (Paper presented at National University of Taiwan, Taiwan, 25 November 2014) 2. Sonoo retired from the Tokyo High Court in November 2014 after a long and prestigious judicial career. Sonoo is now Of Counsel at a leading commercial law firm in Japan, Nishimura \& Asahi.

${ }^{10}$ Proposals to set insolvency practitioner fees were rejected by the Senate Economic References Committee in Australia, because 'setting scale rates of fees would further distort the already distorted market for IPs' services'. See Jennifer Dickfos, 'The Regulation of Corporate Insolvency Practitioners: 25 Years on from The Harmer Report (or Everything Old is New Again!)' (2014) 2 Nottingham Insolvency and Business Law e-Journal 3, 39. 
Fourthly, this article examines the increasing prevalence of pre-petition restructuring in Japan that prima facie appears to allow for greater freedom to set remuneration as between the insolvency practitioner and client where a bengoshi acts as an adviser to the debtor but is not formerly appointed by a court. Concerns about the appointment and remuneration of restructuring experts are not unique to Japan. ${ }^{11}$ In reality, pre-petition restructuring is often still ultimately supervised by the court in Japan when the cases move from private to formal proceedings. The article analyses a case where the remuneration of the pre-petition practitioner was challenged as a voidable transaction by the insolvency practitioner subsequently appointed by the court. ${ }^{12}$ Further, pre-petition practitioners also need to have regard to their reputations amongst judges and court clerks to the extent that they seek to continue to do court-appointed work. Accordingly, the relationship between the court and the practitioners remains important. Finally, this article argues that the increase in out-of-court external appointments, other changes in Japanese insolvency practice and current economic circumstances may require a reassessment of Japan's approach to appointing and remunerating insolvency practitioners, and makes some suggestions for reform.

\section{Overview of Japan's insolvency law framework and provisions relating to the appointment and remuneration of insolvency practitioners}

The 1990s saw a decline in the direct influence of so-called main banks in Japan which also meant a move away from the long period where they could dictate terms to debtors and other creditors. ${ }^{13}$ From an insolvency law perspective, banks now operate in a more transparent contemporary environment where they may defer to an external insolvency practitioner such as a member of the Japanese Association of Turnaround Practitioners ("JATP") as part of an out-ofcourt proceeding. The workout team builds consensus amongst creditors to reach a resolution which may then be confirmed by a court as part of a formal proceeding. ${ }^{14}$ These changes are inextricably linked to the emergence of a global capital market in Japan, which involves participation by foreign creditors including hedge funds, and experienced practitioners who looked to other markets for innovative ways to resolve Japan's bad debt crisis. ${ }^{15}$

\footnotetext{
${ }^{11}$ See e.g., Huxtable, in the matter of Calnan Oldfield Pty Ltd (ACN 120195833 ) (Administrator Appointed) (2010) FCA 769. Mr Huxtable's independence was at issue in this case. He provided advice to a director of the company in relation to insolvency procedures generally and was subsequently appointed as administrator to the company. His appointment was opposed by another director and shareholder of the company.

${ }^{12}$ On this issue, see also, Sato, 'Mushō kōi hi'nin to sagai kōi hi'nin no kankei: dairi'nin no hōshū hi’ nin jiken kara kangaeru' (n 3) 266-270.

${ }^{13}$ Compare Yoshiro Miwa and J. Mark Ramseyer, 'Does Relationship Banking Matter? The myth of the Japanese Main Bank’ (2005) 2(1) Journal of Empirical Studies 261-302.

${ }^{14}$ Interview with Dr Shinjiro Takagi (Melbourne Law School, Australia, 4 November 2015). Cited with permission. Dr Takagi is a founding member of the JATP.

${ }^{15}$ Sakai et al. (n 5).
} 
At the same time, Japan significantly reformed its insolvency legislation, coinciding with global efforts to modernise and formalise existing procedures and following reforms to its financial laws. ${ }^{16}$ Japan's courts also started to take a less instructive role in formal proceedings and focused more on case management, making it difficult to receive extensions of time, for example. ${ }^{17}$ Yet, overall the Japanese financial markets remain largely driven by financial institutions which have an influential say in the resolution of financially distressed companies, and a formal insolvency framework under the heavy influence of the courts as demonstrated by the case studies examined in this article.

The drivers for Japan's insolvency law reform commencing in the 1990 s were multifaceted. ${ }^{18}$ One argument for reform included ridding this area of economic life of anti-social forces which were arguably encouraged to flourish due to the inefficiencies of formal proceedings. ${ }^{19}$ At the time, most of the workout expertise resided in main banks which traditionally intervened in failing companies and helped to avoid formal proceedings. Early intervention by the bank left other creditors without influence over proceedings and precluded the participation of distressed asset investors such as hedge funds which showed an interest in investing in Japan as its economic malaise continued throughout the 1990s. The lack of formal proceedings also reflected a lack of public disclosure and transparency which did not correspond well with other reforms to Japan's financial industry legal framework aiming at more transparency. The Asian Financial Crisis in 1997 further focused Japanese reformers on the task of updating and modernizing Japan's insolvency framework which dated back to the 1920s and was based on 19th century European statutes.

The reform effort culminated in a new, so-called debtor-in-possession (DIP) procedure under the Civil Rehabilitation Act (Act No. 225 of 1999) ("Civil Rehabilitation Act" or "CivRA"), substantial amendments to the Corporate Reorganisation Act (Act No. 154 of 2002) ("Corporate Reorganisation Act" or "CorpRA"), Bankruptcy Act (Act No. 75 of 2004) ("Bankruptcy Act" or "BA") and special liquidation procedure under the Companies Act (Act No. 86 of 2005), and the later introduction of a new alternative dispute resolution procedure which mimics informal

\footnotetext{
${ }^{16}$ For a detailed analysis of Japanese insolvency law provisions, see Stacey Steele and Jin Chun, Insolvency Law, Japanese Business Law (CCH, 2015) (Loose-leaf, as at 26 November 2015).

${ }^{17}$ Interview (n 7) (27 November 2014). The interviewee, a very experienced insolvency practitioner who was already practicing in the 1990s, argued that judges were previously too concerned about saving the company to preserve jobs and thus granted numerous extensions if there was a chance that jobs would be preserved. Accordingly, reorganisations could take up to ten years and did not focus on selling the business as a going concern and using the money to pay creditors.

${ }^{18}$ On the background to the reforms, see Steele and Chun (n 16), para 19-130.

${ }^{19}$ Sonoo (n 9). Other legislative and regulatory action has been taken by Parliament and the Financial Services Agency to reduce the influence of anti-social forces in Japanese economic life. E.g., Securities Business Division Supervisory Bureau FSA, 'Comprehensive Guidelines for Supervision of Financial Instruments Business Operators, etc.' (September 2015), available at: 〈www.fsa.go.jp/en/refer/guide/instruments.pdf〉.
} 
workout procedures. ${ }^{20}$ Individuals may access the procedures under the Bankruptcy Act and Civil Rehabilitation Act and there are modified regimes for special debtors such as financial institutions and insurers, as well as procedures for cross-border insolvencies. ${ }^{21}$ English translations of the relevant insolvency legislation may be found on the Ministry of Justice's Japanese Law Translation website. ${ }^{22}$

Filings increased overall around the time the legislation became effective. ${ }^{23}$ More recently, however, the number of formal filings has decreased. ${ }^{24}$ In 2003 , there were 251,000 bankruptcy case (including 242,849 personal bankruptcy cases), 63 corporate reorganisation cases, and 24,553 rehabilitation cases (941 ordinary rehabilitation cases, and 23,612 individual rehabilitation cases). ${ }^{25}$ In comparison, in 2014, there were 73,368 bankruptcy cases (including 65,393 personal bankruptcy cases), four corporate reorganisation cases, and 7,833 civil rehabilitation cases (165 ordinary civil rehabilitation cases, and 7,668 individual rehabilitation cases). ${ }^{26}$ Individual bankruptcy applications in particular have declined dramatically, with corporate bankruptcies increasing from 3203 cases in 2000 to 7881 cases in $2015 .^{27}$ A key reason for the decreasing number of personal bankruptcies is a Supreme Court of Japan judgement against the money lending industry which required money lenders to pay back overpayment of interest above what was set under the Interest Rate Restriction Act (Act No. 100 of 1954). Debtors have since been able to recover any overpayments and avoid bankruptcy. ${ }^{28}$

${ }^{20}$ Saiban gai funsō tetsuzuki no riyō no sokushin ni kansuru hōritsu (Law in relation to Promotion of the Use of Outof-Court Dispute Resolution Proceedings) (Act No 151 of 2004).

${ }^{21}$ For a discussion of these proceedings, see Steele and Chun (n 16).

${ }^{22}$ Ministry of Justice, Japanese Law Translation, available at: <www.japaneselawtranslation.go.jp>. Translations are by the author or Mr Kaori Kano, Principal Research Assistant. On the reliability and translation process for the Ministry of Justice translation project, see Carol Lawson, 'Found in Translation: The 'Transparency of Japanese Law Project' in Context' (2007) 24 Journal of Japanese Law 187.

${ }^{23}$ Kent Anderson, 'Japanese Insolvency Law after a Decade of Reform' (2006) 43(1) Canadian Business Law Journal 2, 15.

24 Courts in Japan, 'Dai 2 bu Jiken no tōkei' (2nd Division Summary of Cases), available at: <www.courts.go.jp/vcms_lf/05_p33-p53.pdf>. These trends are also discussed in Kazuhiko Yamamoto and Ken Yamamoto (eds), Minji saisei hō no jisshōteki kenkyū (Empirical Research on the Civil Rehabilitation Act) (Shōji hōmu, Tokyo, 2014) 309.

${ }^{25}$ Ibid

${ }^{26}$ Ibid. On the decline of formal insolvency proceedings and rise of informal workouts, see: Takashi Sonoo, 'Hōteki seiri to shiteki seiri wa kongo doko ni mukau no ka - Tōsan jiken genshō no haikei to shōrai tenbō' (Where are legal workout and private workouts going now?) (2016) 2050 Kinyū hōmu jijōo (Financial Law Journal) 6, 10.

${ }^{27}$ Ibid 11 .

${ }^{28}$ On legislation and case law relating to grey-zone interest, see Souichirou Kozuka and Luke Nottage, 'Unsecured Lending in Japan' in Johanna Niemi et al. (eds), Consumer Credit, Debt and Bankruptcy: Comparative and International Perspectives (Hart Publishing, Oxford, 2009) 202. 
Other reasons for the decreasing number of filings include the current benign interest rate environment in Japan. ${ }^{29}$ Further, corporate debtors may be more reluctant to file for rehabilitation as they have come to realise that the new proceedings often facilitate a so-called business transfer-style rehabilitation rather than a so-called reconstruction-style rehabilitation. ${ }^{30}$ Formal filings may also have reduced during the period between 2009 and 2013 due to the government's policy of supporting small-medium enterprises, as reflected by the activities of Chūshō kigyō saisei shien zenkoku honbu (SME Rehabilitation Support National Head Office). The Head Office was established within SME Support, Japan in 2007 by the Ministry of Economy, Trade and Industries, and it has a branch in each prefecture. ${ }^{31}$ The number of companies who received support from the Chūshō kigyō saisei shien kyōgikai increased from 438 cases in 2005 to 2848 case in $2014 .^{32}$

Government support is also evidenced by the establishment of the Kigyō saisei shien kikō in 2009 which was managed by the Ministry of Finance and incorporated into the Chi'iki keizai kasseika shien kikō (Regional Economy Revitalization Corporation of Japan (REVIC)) in 2013. ${ }^{33}$ Since the reforms, a number of large corporate insolvencies in Japan have proceeded under the business enterprise ADR procedure and also informally. ADR and informal workouts are an important area of insolvency practice in Japan discussed in this article in the context of prepackage cases and petitioning representative remuneration.

\section{A Bankruptcy Proceedings}

\footnotetext{
${ }^{29}$ Interview with Takagi (n 14).

${ }^{30}$ Nakai notes that the reason for the decrease in filings may be due to Chūshō kigyō ni taisuru kinyū no enkatsuka wo hakaru tame no rinji sochi ni kansuru naikakufurei (Cabinet Office Ordinance on Handling of the SME Finance Facilitation) (Ordinance no 72, 2009) which expired in March 2013. See Masaaki Oka et al., 'Zadankai 'Minji saisei hō no jisshōteki kenkyū' wo fumaete - Jitsumu no shiten, riron kara no gimon' (Roundtable Discussion, based on the 'Empirical research on the Civil Rehabilitation Act' - Questions arising from the Practical Viewpoint and Theory) in Yamamoto and Yamamoto (n 24) 309. Also see Sonoo (n 26) 9-10. According to Sonoo, this Cabinet Office Ordinance was designed as a temporary measure to avoid SME bankruptcies immediately after the 'Lehman shock'. However, it was extended twice including because of adverse economic effects of the Great East Japan Earthquake (March 2011). The number of the civil rehabilitation cases in particular reduced dramatically, and the number of private workout cases increased whilst this Ordinance was effective. Even after the expiry of the Ordinance, the government continues to encourage creditors to refrain from accelerating loans, which means the low number of formal filing will continue according to Sonoo.

${ }^{31}$ Yamamoto and Yamamoto (n 24) 310; Sonoo (n 26) 9.

${ }^{32}$ The number of insolvency case grew from 7905 in 2005 to 9180 in 2014, whereas the number of formal civil rehabilitation proceedings decreased from 646 cases in 2005 to 165 cases in 2014, and the number of corporate reorganization cases decreased from 44 cases in 2005 to 4 cases in 2014: Nishimura \& Asahi and Frontier Management (eds), Hōteki seiri keikaku sakutei no jitsumu (Shōji hōmu, Tokyo, 2016) (1); Sonoo (n 26).

${ }^{33}$ Sonoo (n 26) 9. These organisations also built on developments such as the introduction of the Shiteki seiri ni kansuru gaidorain (Guidelines in relation to Private Workout) in 2001, and the establishment of the Sangyo saisei $k i k \bar{o}$ (Industrial Revitalization Corporation (IRC)) in 2003 by the Ministry of Finance.
} 
The reform of the bankruptcy procedure in 2004 was the first major overhaul of the legislation since 1922. The purpose of bankruptcy proceedings in Japan is to liquidate or discharge the debtor when the debtor is already unable to pay its debts (BA Arts 15-16). Following a petition to commence a bankruptcy proceeding, the court may order pre-commencement preservation measures on a case-by-case basis (BA Arts 24-28), including the appointment of a provisional trustee. A debtor loses its right to control its assets at the commencement of a proceeding, and the appointed trustee takes complete and immediate control (BA Art 78(1)). Trustees are typically bengoshi. Ordinary creditors are also generally prohibited from exercising their rights outside of the proceeding (BA Art 42). Secured creditors with a right of separate satisfaction (betsujo ken, BA Arts 65-66) and those with rights of set-off (sōsai ken, BA Arts 67-73), however, are not subject to a stay. Once appointed, the trustee is obligated to manage and dispose of the debtor's assets (BA Arts 78-90). The trustee is required to distribute any proceeds from the disposition of the assets in accordance with the legislated priority (BA Arts 184-215) based on claims submitted by creditors and confirmed by the trustee (BA Arts 111-134). A bankruptcy proceeding involving a corporate debtor culminates with the dissolution of the corporate entity at the termination of the proceeding (BA Art 35). A personal bankruptcy case typically ends with the discharge of the bankrupt (BA Art 253(1)). ${ }^{34}$

A trustee is entitled to receive remuneration and expenses prior to the completion of the proceeding (BA 87(1)) and the trustee's right to payment is categorised as a claim on the estate (that is, an administrative expense) (BA 148(1)(i) and 152(2)). Accordingly, the trustee's right to payment has the highest priority of unsecured claims. As highlighted further below, however, there are no detailed legislative provisions about how the remuneration is to be calculated other than Rule 27 of the Bankruptcy Rules which requires the court to set the remuneration at an amount which is appropriate for the tasks and responsibilities involved in the matter. ${ }^{35}$ Further, many personal bankruptcy proceedings are dealt with as asset-less or small-scale cases and the remuneration of the trustees in these cases are set by the relevant court as examined below.

\section{B Corporate Reorganisation Proceedings}

The corporate reorganisation procedure was initially introduced into Japan in $1952 .{ }^{36}$ Corporate Reorganisation is a special procedure designed exclusively for kabushiki gaisha or stock corporations (CorpRA Art 1). Given the large size of debtors which use this procedure, it is not surprising that there are comparatively less filings than bankruptcy and civil rehabilitation

\footnotetext{
${ }^{34}$ For an overview of the current Japanese personal insolvency law, see Junichi Matsushita, 'Japan's Personal Insolvency Law' (2007) 42 Texas International Law Journal 765-771.

${ }^{35}$ Takeshita et al. argue that Rule 27 of the Bankruptcy Rules (Hasan kisoku, Supreme Court Rule No. 14 of 2004) was introduced to discourage the practice of approving low remuneration to secure a high distribution to the creditors. The Rule requires courts to set remuneration at a level which reflects the duties and responsibilities of the trustee. See Morio Takeshita et al. (eds) Daikonmentaaru hasanhō (Key Commentary on Bankruptcy Law) (Seirin Shoin, 2007) 369 .
} 
petitions and, to the extent that there are filings, cases are typically commenced in Tokyo and Osaka, the commercial centres of Japan. ${ }^{37}$ The fundamental structure of corporate reorganisation proceedings is the same as for civil rehabilitation proceedings discussed below, but there are key distinguishing features arising out of its special focus on large stock corporations. Similarly to bankruptcy and by contrast with civil rehabilitation, the legislation requires the court to appoint a trustee (CorpRA Art 42).

The court has the power to decide the trustee's remuneration (CorpRA Art 81). ${ }^{38}$ Rule 22 of the Corporate Reorganisation Rules provides that the court must decide the remuneration of a trustee, trustee's representative, and legal counsel (höritsu komon) which is appropriate in light of the tasks performed and the responsibility undertaken (Supreme Court Rule No. 2 of 2003). Trustees are typically bengoshi. By contrast with bankruptcy and civil rehabilitation, secured creditors are generally restricted from enforcing security to facilitate the goal of reorganisation by retaining assets which are essential to the debtor's business (CorpRA Arts 2(10)-(12), 47(1)). Finally, corporate reorganisation is also characterized by reorganisation plans which alter the debtor's corporate structure, including company splits and mergers (CorpRA Arts 174-183, 210-225). Company transformation under the umbrella of a reorganisation plan potentially avoids complex rules which would apply to similar transactions carried out under the Companies Act (Act No. 86 of 2005).

A corporate reorganisation proceeding will not be terminated by a court until the plan has been completely performed or the payments under the plan have been substantially performed or the court is confident in the prospects for its performance (CorpRA Art 239). The requirements for approval of a proposed reorganization plan depend on the plan's contents. Typically, approval of a reorganisation plan requires agreement from more than 50 percent of unsecured creditors by amount (CorpRA Art 196(5)(i)). In the case of a "[p]roposed reorganization plan which provides for the extension of the terms of secured reorganization claims", approval requires agreement from at least two-thirds of secured creditors by amount (CorpRA Art 196(5)(ii)(a)). For a "[p]roposed reorganization plan which provides for the reduction and release of debts for secured reorganization claims or provides for measures that may affect the rights of secured reorganization creditors other than the extension of terms", approval requires agreement from at least three-quarters of the secured creditors by amount (CorpRA Art 196(5)(ii)(b)). For "[p]roposed reorganization plan which aims for the discontinuation of the entire business of the reorganization company", approval requires agreement from at least nine-tenths of secured

\footnotetext{
${ }^{36}$ On the background to the corporate reorganisation proceeding, which was initially based on the old Chapter X of the Bankruptcy Act of the United States of America (1938), see Steele and Chun (n 16) para 19-480. Kabushiki gaisha are companies limited by shares. Companies do not have to be publicly listed to use the corporate reorganisation proceeding.

${ }^{37}$ Sonoo (n 9) 2.

${ }^{38}$ Ibid. The court may, however, allow a corporate reorganisation proceeding to commence in substance as a debtorin-possession case in exceptional circumstances as discussed below.
} 
creditors by amount (CorpRA Art 196(5)(ii)(c)). It typically takes six to ten months from commencement of a proceeding to obtain approval for a plan, but plans may be approved as quickly as three months where they contain provisions for a business transfer and a sponsor exists. ${ }^{39}$

\section{Civil Rehabilitation Proceedings}

The new civil rehabilitation proceeding was established to enable both individuals and corporate debtors to rehabilitate by way of performing a rehabilitation plan when the debtor has not yet become unable to pay its debts, but there is the risk of an inability or serious difficulty in paying (CivRA Art 21). The procedure was designed to be used mainly, but not exclusively, by small and medium-sized enterprises. Recent empirical research on Japanese civil rehabilitation cases provides interesting insights into the procedure, particularly during its first decade. ${ }^{40}$ The researchers reviewed 313 civil rehabilitation cases consisting of all recorded cases heard in the Sendai District Court (59 cases) and Naha District Court (44 cases) from 2000 to 2010, 55 Tokyo District Court cases and 50 Osaka District Court cases recorded about the time of the enactment of the Civil Rehabilitation Act, and 55 Tokyo District Court cases and 50 Osaka District Court cases from more recently completed and recorded cases. ${ }^{41}$

The survey shows that the 313 rehabilitation cases related to 270 kabushiki gaisha (stock corporations), 29 yügen gaisha (limited companies), five göshi gaisha (joint partnerships), two kyōdō kumiai (co-operative associations), two tōshi hōjin (investment corporations) and five iryō hōjin (medical corporations). ${ }^{42}$ The key industries using civil rehabilitation were manufacturing ( 85 cases), services (61 cases), construction (59 cases) and commerce (57 cases). ${ }^{43}$ Most of the entities had between JPY 10 million and JPY 30 million in capital (114 entities, 36.4 percent), although some larger entities with capital amounts of between JPY 30 million and JPY 50 million also used the procedure (71 entities, 22.7 percent). ${ }^{44}$ Japanese courts approved an order to commence a civil rehabilitation proceeding for approximately 90 percent of all petitions filed and commencement orders are usually provided within one week of filing in Tokyo. ${ }^{45}$

${ }^{39}$ Ibid

${ }^{40}$ See Yamamoto and Yamamoto (n 24).

${ }^{41}$ Ken Yamamoto et al., 'Jittai chōsa no gaiyō' (Overview of Survey) in Yamamoto and Yamamoto (n 24$) 4$. Mayumi Kurabe and Ken Yamamoto, 'Saisei tetsuzuki ni okeru betsujoken no shogū' (Dealing with Rights of Separate Satisfaction in Rehabilitation Proceeding) in Yamamoto and Yamamoto (n 24) 211.

${ }^{42}$ Yamamoto et al. (n 41) 9.

${ }^{43}$ Ibid 10.

${ }^{44}$ Ken Yamamoto, 'Saisei Saimusha - Jisshō data kara yomitoku Saisei tetsuzuki no riyōshazō' (Rehabilitation Debtors - Portrait of Users of Rehabilitation Proceeding analyzed from Empirical Data) in Yamamoto and Yamamoto (n 24) 40.

${ }^{45}$ Yamamoto et al. state that 299 out of 313 applications (91.6 percent) received commencement orders. The average time taken for commencement order is 18.45 days overall: Yamamoto et al. (n 41), 13. Hatake and Kondo also state that the average time is shorter at Tokyo District Court with 8.88 days (average 6.88 days in more recent 
The key difference between civil rehabilitation proceedings on the one hand, and bankruptcy and corporate reorganisation proceedings on the other hand, is that debtors typically remain in control of their assets and may continue their business under civil rehabilitation (CivRA Art 38). These cases are known as debtor-in possession or DIP cases. Trustees are only appointed in exceptional cases (CivRA Art 64(1)). ${ }^{46}$ Recent empirical research shows that trustees were appointed in only four out of 313 cases surveyed, for example. ${ }^{47}$ Chun and Ide argue that the knowledge that a trustee will be appointed and that management will lose office would generally discourage Japanese management teams from filing. ${ }^{48}$ Reformers and courts appear to have acknowledged the chilling effect of mandatory trustee appointment, but they retained the court's ability to appoint a trustee in exceptional cases where the debtor acts extremely unfairly. ${ }^{49}$ Furthermore, the court usually appoints a supervisory officer known as a kantoku i'in (CivRA Art 54) even in civil rehabilitation DIP cases. ${ }^{50}$ Kantoku i'in or supervisors are typically bengoshi and act under the supervision of the court (CivRA Arts 57 and 63). Kantoku i'in were appointed in 307 out of 313 rehabilitation cases surveyed (98.1 percent of cases). ${ }^{51}$

The civil rehabilitation procedure allows for other supervisory appointments, but these are rare as confirmed by the empirical survey: chōsa i'in (investigators) were appointed in two cases and a hozen kanri nin (provisional administrator) was appointed in one case (CivRA Arts 79-83). ${ }^{52}$ Interested parties may apply, or the court may determine on its own motion, to give the supervisor authority to exercise avoidance powers (hi'ninken) once a civil rehabilitation proceeding is commenced (CivRA Art 56(1)), in which case the supervisor may also be given authority to manage and dispose of the monetary earnings/expenses and other assets of the debtor (CivRA Art 56(2)). The court decides the supervisor's remuneration (CivRA Art 61), but similarly to other formal Japanese proceedings there are no details on the method for calculating

cases): Hiroki Hatake and Takashi Kondo, 'Saisei tetsuzuki ni yōsuru kikan — saisei tetsuzuki kaishi no mōshitate kara saisei keikaku no ninka made' (Time required for Rehabilitation Proceeding — From the Petition for Rehabilitation Proceeding to the Approval of Rehabilitation Plan) in Yamamoto and Yamamoto (n 24) 21. See also Sonoo (n 9) 1.

${ }^{46}$ Sonoo (n 9) 1.

${ }^{47}$ Junko Uezu, 'Saisei tetsuzuki no kikan / hiyō — Jisshō dēta kara mieru tetuzuki kikan no yakuwari' (Institutions and Costs of Rehabilitation proceedings - Roles of Proceeding Institutions seen from Empirical Data) in Yamamoto and Yamamoto (n 24) 68.

${ }^{48}$ Chun and Ide (n 6) 400.

${ }^{49}$ See comments by Parliamentary Vice Minister Yamamoto in 'Dai 146 kai kokkai hōmu i'inkai dai 7 gō kai giroku' (Minutes of 146th Meeting of House of Representatives, 7th Meeting of the Judicial Affairs Committee) from 19 November 1999, available at:

<www.shugiin.go.jp/internet/itdb_kaigiroku.nsf/html/kaigiroku/000414619991119007.htm>.

${ }^{50}$ Yamamoto and Yamamoto (n 24). See also Chun and Ide (n 6) 400. On the various options open to the court to appoint supervisory officers, see Steele and Chun (n 16) para 19-355. On the difference between supervisors and investigators, see Steele and Chun (n 16) para 19-365.

${ }^{51}$ Uezu (n 47) 57.

52 Ibid 68. An Individual Rehabilitation Officer (kojin saisei i'in) may also be appointed (Civ RA Art 223). 
remuneration in the legislation. The Civil Rehabilitation Rules provide that the amount of remuneration of a supervisor, an investigator, a trustee, a provisional administrator or a representative of the provisional administrator set by the court must be appropriate in light of the tasks performed and the responsibility undertaken. ${ }^{53}$

The key focus of a civil rehabilitation proceeding is developing a rehabilitation plan (CivRA Arts 154-185). In contrast to corporate reorganisation, there is no automatic stay on secured creditors enforcing their security, although the court may order a moratorium after a rehabilitation petition has been filed in certain circumstances (CivRA Art 31). ${ }^{54}$ Courts grant stays against secured creditors in very rarely, ${ }^{55}$ but secured creditors reach an agreement involving amending or suspending security rights voluntarily in the majority of cases. ${ }^{56}$ These findings reflect the importance of obtaining secured creditor support if a civil rehabilitation plan is to be successful. Financial institutions are particularly aggressive when it comes to valuations, and agreement about a plan is unlikely to be reached where there is disagreement about the value of any collateral real estate. ${ }^{57}$ Corporate reorganisation proceedings may be more appropriate if it is unlikely that the secured creditors will agree to the rehabilitation plan, because an automatic stay is available under the corporate reorganisation proceeding. ${ }^{58}$

The ultimate goal in civil rehabilitation proceedings is for a plan to reduce a debtor's liabilities and, hopefully, enable the debtor to rehabilitate the business. Of the 313 cases surveyed by Japanese researchers, 232 completed a rehabilitation proceeding by either implementing an approved rehabilitation plan, or completing a supervisor's or trustee's plan. ${ }^{59}$ Debtors and other interested parties may submit a rehabilitation plan that modifies a creditor's rights and payment conditions (CivRA Arts 154-162, 163), although unsecured creditors must generally be treated equally with some exceptions (CivRA Art 155(1)-(2)). The national average length of time between petition to the approval of the plan is 240.77 days ( 8 months), with a shorter average of

\footnotetext{
${ }^{53}$ Civil Rehabilitation Rules (Minji saisei kisoku) (Supreme Court Rule No. 3 of 2000). In relation to supervisors, Rule 25 of the Civil Rehabilitation Rules states: 'Saibansho ga sadameru kantoku i'in no hōshü no gaku wa, sono shokumu to sekinin ni fusawashii monode nakereba naranai' (The remuneration amount for a supervisor set by the court must be appropriate in light of the tasks performed and the responsibility undertaken). Rule 26(2) provides that Rule 25 also applies to investigators, and Rule 27 provides that Rule 25 also applies to trustees, trustee representatives, provisional administrators and provisional administrator representatives.

${ }^{54}$ On the treatment of secured creditors, see Steele and Chun (n 16) para 19-385; Stacey Steele, 'Too Hot to Handle: Extinguishing Secured Creditors' Interests in Insolvency Under Japan's Civil Rehabilitation Law' (2003) 16 Journal of Japanese Law 223, 228-30.

${ }^{55}$ Kurabe and Yamamoto (n 41) 211.

${ }^{56}$ Ibid 206.

${ }^{57}$ Ibid 208.

${ }^{58}$ Sonoo (n 26) 12. Sonoo, however, explains that there are other hurdles to using corporate reorganization such as higher yonōkin costs.

${ }^{59}$ Yamamoto et al. (n 41) 18.
} 
193.43 (6.5 months) for cases in Tokyo. ${ }^{60}$ A quarter of proceedings (81 out of 313 cases) were not completed and the majority of these ( 74 cases) ended in bankruptcy. ${ }^{61}$

Once a plan has been approved by 50 percent of eligible creditors by number and total claims (eligible creditors are unsecured creditors, and secured creditors for the amount they were unable to recover from enforcement of their security (CivRA Arts 87-88)) and finalized via court approval (CivRA Arts 169-185), unsecured creditors are bound by the plan and debts may be repaid by the debtor only according to the plan (CivRA Arts 177-185). A civil rehabilitation proceeding may be concluded once a plan has becomes final. Where a supervisor or trustee has been appointed, however, the proceeding and supervision may be extended ostensibly to secure performance of the plan under supervision (CivRA Art 188). The survey suggests that as many as three-quarters of plans are completed. ${ }^{62}$

\section{Evolution of the process for appointing trustees to bankruptcy and corporate reorganisation cases: innovations from the Tokyo District Court}

These decade-long reforms to insolvency proceedings and practice, coupled with continuing poor economic and trading conditions, saw insolvency law and restructuring emerge as a viable practice area for many bengoshi. Until the late 1990s, insolvency law was a very rare form of specialization for practitioners. Accordingly, at the turn of the 21st Century, the Tokyo District Court faced a human resource and knowledge gap when considering the appointment of trustees, particularly in light of the demand generated by the reforms and economic conditions. ${ }^{63}$ This section of this article focuses on Tokyo, the busiest insolvency jurisdiction in Japan. Japan does not have special courts for insolvency proceedings, but in large commercial jurisdictions such as Tokyo and Osaka there are special divisions of the District Courts designated as having responsibility for hearing insolvency cases and the personnel in these divisions build up expertise in the jurisdiction. The Tokyo District Court has special jurisdiction over large insolvency matters, which means it oversees the most complex, diverse and large corporate collapses in Japan as well as a large volume of smaller cases. Over the last two decades it has also been a centre of innovation for judicial practice in insolvency matters. Even now that insolvency law is one of the most popular elective subjects on the Japanese national bar examination, ${ }^{64}$ however,

\footnotetext{
${ }^{60}$ A longer average of 358.43 (12 months) was found for cases from the regional court in Naha. Hatake and Kondo (n 45) 35 .

${ }^{61}$ Yamamoto et al. (n 41) 19.

${ }^{62}$ Ibid.

${ }^{63}$ On the increase in filings for formal insolvency proceedings around this time, see Anderson (n 23$) 13$.

${ }^{64}$ Candidates are only expected to know about bankruptcy and, since 2005, civil rehabilitation proceedings. Corporate reorganisation has never been required learning for this elective on the bar examination, probably in light of the small number of cases both historically and even after its reform in 2002. See Stacey Steele, 'Japan's National Bar Examination: Results from 2015 and Impact of the Preliminary Qualifying Examination' (2016) 41 Journal of Japanese Law 55-75; Stacey Steele and Aya Haruyama, 'Japanese Bar Examination Questions and Student
} 
the number of judges and practitioners who practice in insolvency matters in the greater metropolitan Tokyo area is still not large. ${ }^{65}$

The analysis in this section focuses on bankruptcy and corporate reorganisation proceedings, because trustees are rarely, if at all, appointed by courts in civil rehabilitation cases. ${ }^{66}$ Given that debtors lose rights to control assets in favour of the trustee, the trustee plays a central role in the whole bankruptcy or corporate reorganisation proceeding under the supervision of the court (BA Art 75, CorpRA Art 68). ${ }^{67}$ During the proceeding, for example, the trustee is charged with inspecting and confirming claims from creditors, distributing proceeds and, if relevant, performing the reorganisation plan. Trustees are authorized to exercise a broad range of powers, including avoidance powers (hi'ninken, BA Arts 160-176, CorpRA Arts 86-98). Trustees are also under the duty of reasonable care of a good manager, and are personally liable for a breach of that duty (BA Art 85, CorpRA Art 80). ${ }^{68}$

Reforms to the Bankruptcy Act and Corporate Reorganisation Act provided for the appointment of juridical persons, such as law firms, to serve as trustees (BA Art 74(2), CorpRA Art 67(1)). Reformers also sought to open up restructuring to professionals other than bengoshi; for example, business people and accountants with turnaround experience, but in most cases courts still appoint individual bengoshi. ${ }^{69}$ The Tokyo District Court does not appoint juridical persons, because judges, who control appointments, perceive individual appointments as driving home responsibility to the trustee. ${ }^{70}$ Courts may appoint more than one trustee (BA Art 76(1), CorpRA Art 69(1)), but this is also unlikely in the context of their focus on individual responsibility and

Preferences: Why do more Students choose Insolvency Law over Public International Law and why does it matter?' (2016) 42 Journal of Japanese Law 1-29. Sonoo (n26) suggests, however, even more recently that fewer students are taking insolvency law classes at law schools.

${ }^{65}$ Dr Takagi notes, for example, the number of people in Japan who are registered insolvency practitioners for Business Revitalization ADR purposes and accredited by the Ministry of Justice and Ministry of Economy, Trade and Industry is quite small. Interview with Takagi (n 14). On ADR for business revitalization, see Steele and Chun (n 16) para 19-645.

${ }^{66}$ As discussed above and below, courts are likely to appoint a supervisor in a civil rehabilitation proceeding. Uezu (n 47) 57.

${ }^{67}$ As discussed above, under bankruptcy and corporate reorganisation proceedings, a trustee must be appointed by the court (BA Arts 31(1), 74(1), CorpRA Arts 42(1), 67(1)).

${ }^{68}$ Under the Corporate Reorganization Act, see for example, Articles 46(2), 68(1), 72(2), 78(1), 79(1), 80(1)-(2) and 81(2). See also the materials cited above in relation to this duty (n 2).

${ }^{69}$ In Kazuhiko Yamamoto, Tōsan shori hō Nyūmon Dai 4 han (Introduction to Insolvency Law (Fourth Edition)) (Yuhikaku, Tokyo, 2012) 67, Yamamoto notes one case where a doctor was appointed as trustee for a hospital in bankruptcy because it involved the transfer of in-patients from that hospital to another hospital. See also Sato, 'Kanzai nin seido ni miru nichi doku chū no hikaku' (n 3) 55, who cites the appointment of the Enterprise Revitalization Support Organisation as a member of the trustee group for reorganisation proceeding of the JAL group.

${ }^{70}$ Email from Sonoo to author (19 January 2015). Email on file with author. Cited with permission. 
the expectation that responsibility should not be shared. ${ }^{71}$ It is more likely that the trustee will be given permission by the court to appoint a trustee representative such as an accountant who will work with the trustee on the matter under the trustee's supervision (BA Art 77(2), CorpRA Art 70(2)). Courts also privilege legal practitioners because the relevant judges perceive that legal knowledge is essential in insolvency cases; it is believed to be efficient to appoint a bengoshi, because bankruptcy cases may involve lawsuits; and bengoshi have high professional and ethical standards, and there is a well-structured, self-regulating disciplinary mechanism in the form of bar associations. ${ }^{72}$

In the absence of other formal requirements for the appointment of trustees, each district court in Japan has developed internal standards. Factors which are normally taken into account include: the degree of difficulty of the case; past experience and performance as a trustee; number of years as a legal practitioner; number of other cases where the same candidate has been appointed as a trustee and his or her performance in those other cases; size and staffing of the law firm that the candidate belongs to; and whether there may be a conflict of interest. ${ }^{73}$ Despite district courts making a serious effort to equalize the factors taken into account in the trustee appointment process, the process has typically been left to the discretion of the relevant district court and details of each process are not public. Experienced practitioners concur, however, that these are the types of factors that courts seem to consider when appointing a trustee. ${ }^{74}$

Greater rigour was introduced into the process of choosing and appointing insolvency practitioners, including trustees at the Tokyo District Court, around the time of the introduction of the civil rehabilitation proceeding in $2000 .{ }^{75}$ Prior to 2000 , even in a busy jurisdiction like Tokyo, trustees could be appointed on the basis of an individual judge's views about the competency of an individual bengoshi. ${ }^{76}$ The drastic increase in filings meant a sudden increase in demand for bengoshi who could act as trustees, and the model of relying on individual judicial knowledge about trustees was no longer sustainable. ${ }^{77}$ The Tokyo District Court judges and court clerks pooled their knowledge to create a list of eligible bengoshi who could act as trustees known as the 'List of people qualified to act as bankruptcy trustees (hasan kanzai nin

\footnotetext{
${ }^{71}$ A bengoshi's professional indemnity insurance would typically cover the situation where there is an indemnity claim against a bengoshi who is acting as a trustee. Email from Takashi Sonoo to author (11 July 2016). Email on file with author. Cited with permission.

${ }^{72}$ See Saibansho shoku'in sōgō kenshū jo (Training and Research Institute for Court Officials), Hasan jiken ni okeru Shokikan jimu no kenkyū - höjin kanzai jiken wo chüshin toshite (Research for court clerk practice in bankruptcy cases - Focusing on corporate trustee cases) (Shihō Kyōkai, Tokyo, 2013) 31. See further below on the role of bar associations.

${ }^{73}$ Ibid 32. On conflicts of interest, see Yasuki (n 2) and the discussion of Yasuki's findings below.

${ }^{74}$ Interview (n 7) (27 November 2014).

${ }^{75}$ Sonoo (n 9) 4.

${ }^{76}$ Ibid.

${ }^{77}$ Ibid.
} 
tekikakusha meibo)' ("List"). ${ }^{78}$ This process highlights the important role that court clerks also play in the appointment of trustees in Japan. Court clerks are highly trained and knowledgeable, and obtain experience throughout the court system with transfers typically every three years. One judge noted that in his court the ratio of judges to clerks was one to eight, and the clerks tended to have worked in the area of insolvency in the courts previously, giving them practical expertise which was valuable to the judges who also transfer courts every two to three years. ${ }^{79}$

As Tokyo sought to systemise appointments at the turn of the Century, eligible bengoshi were split into three groups: first, those bengoshi with no or little experience as trustees (Level 1); secondly, those bengoshi with experience of dealing with insolvency cases of a medium degree of complexity (Level 2); and thirdly, those bengoshi with experience of dealing with complex and difficult cases (Level 3). ${ }^{80}$ The Court allocated trustees on a rotation basis to cases based on the List. ${ }^{81}$ The Tokyo District Court also consulted with the three bar associations based in Tokyo which were providing joint bankruptcy trustee training for bengoshi with no experience of acting as a bankruptcy trustee and, with their co-operation, obtained a list of bengoshi who completed the training. ${ }^{82}$ The names of those bengoshi were added to the List of Level 1 bengoshi. In this way, the Tokyo District Court was able to quickly increase its known bengoshi interested in acting as trustees to 1000 people. ${ }^{83}$ The List of bengoshi is a highly sensitive document, and is strictly an internal working document of the Court. ${ }^{84}$ The Court occasionally deviated from its standard List, for example, in large, specialised, and unique insolvencies. ${ }^{85}$ Yamaichi Securities Co. Ltd, a Japanese securities firm which was declared bankrupt by the Tokyo District Court in June 1999 is one example. ${ }^{86}$ Yamaichi had assets all over the world and significant assets domestically. ${ }^{87}$ The Court appointed Hideki Matsushima of Nishimura \& Asahi to act as trustee based on his knowledge of the industry and capacity to bring about a speedy and efficient resolution. ${ }^{88}$

${ }^{78}$ Ibid. Also in Sato, 'Kanzai nin seido ni miru nichi doku chū no hikaku' (n 3) 54. Sato notes that the courts and bar associations maintain a list of candidates for trustee work, and use it to select the trustee considering the individual cases and conflict of interest.

${ }^{79}$ Interview (n 7) (2 December 2014).

${ }^{80}$ Sonoo (n 9) 4.

${ }^{81}$ Ibid.

${ }^{82}$ Ibid.

${ }^{83}$ Ibid.

${ }^{84}$ Ibid.

${ }^{85}$ Takashi Sonoo, 'Brief History and Recent Development of Business Insolvency Law in Japan' (Melbourne Law School Presentation Paper, 27 July 2015).

${ }^{86}$ Email correspondence from Sonoo to author (18 November 2016).

${ }^{87}$ For Yamaichi Securities' case, see David Hamilton and Bill Spindle, 'Yamaichi Securities shut down in Japan's Biggest-ever Failure' (24 November 1997) The Wall Street Journal, available at: <www.wsj.com/articles/SB880310313773643500>; 'Japan: Banking Crisis' (28 January 1998) BBC News, available at: 〈http://news.bbc.co.uk/2/hi/special_report/1997/asian_economic_woes/34500.stm〉.

88 For information on Hideki Matsushima, see Nishimura \& Asahi, 'Professionals', available at: <www.jurists.co.jp/en/attorney/0001.html>. Matsushima has extensive restructuring experience as does his firm 
The court does not appear to have had a strict due diligence process for issues such as the potential for a trustee to have a conflict of interest as part of the appointment process. Because most trustees are bengoshi, conflicts of interest are arguably already dealt with in the industry code published by the Japan Federation of Bar Association ("JFBA"). ${ }^{89}$ The Bengoshi shokumu kihon kitei (Basic Code of Bengoshi Business) provides that bengoshi must not undertake matters entrusted to her or him by the government or a public agency if the bengoshi is unable to maintain impartiality in performing her or his duty (Item 81$).^{90}$

Academic commentary also gives further colour to the obligations of a bengoshi. Yasuki suggests four situations where the bengoshi should not undertake to act as a trustee, for example. ${ }^{91}$ First, where the bengoshi has been consulted by a creditor regarding the collection of a debt from the debtor who has applied for the insolvency proceeding (see also Attorney Act, Act No. 205 of 1949, Art 25(1)). Secondly, where the debtor who applied for the insolvency proceeding is or has been on the other side of a matter where the bengoshi was or is engaged. Thirdly, where the bengoshi is the legal advisor for one of the petitioning debtor's creditors. Fourthly, where the bengoshi has provided or is providing legal advice to a third-party debtor (dai san saimusha) in a dispute about the existence of a debt between the petitioning debtor and the third-party debtor.

The interaction between the JFBA's industry code and the co-operation of the bar associations with the courts in reviewing and providing suggestions for candidates is another important element of the framework for appointing and supervising trustees in Japan. ${ }^{92}$ Approximately 500 bengoshi take the Tokyo course on insolvency law and practice each year. ${ }^{93}$ In this way, the Court and bar associations act as gatekeepers to trustee work for bengoshi, and bengoshi are required to prove their ability to the Court through the proceedings allocated to them. These training programs are not available nationally, however, given the limited number of bengoshi in some areas in Japan, particularly in regional areas. It is difficult to offer similar training opportunities in smaller jurisdictions, and arguably there is less of a need for a formal training procedure because outside of Tokyo there are fewer bengoshi and cases. Fewer bengoshi and

which represented Japan Airlines (JAL) in its insolvency proceedings. Nishimura \& Asahi, 'Practice Areas: Restructuring / Insolvency', available at: 〈https://www.jurists.co.jp/en/practice/restructuring_01.html>.

${ }^{89}$ Japan Federation of Bar Associations, Bengoshi shokumu kihon kitei (Basic Code of Bengoshi Business), available at: <www.nichibenren.or.jp/library/ja/jfba_info/rules/pdf/kaiki/kaiki_no_70_160525.pdf>.

${ }^{90}$ In Japanese: bengoshi wa, hōrei ni yori kankōsho kara ishoku sareta jikō ni tsuite, shokumu no kōsei wo tamochienai jiyū ga aru toki wa, sono ishoku wo ukete wa naranai.

${ }^{91}$ Yasuki (n 2) 519.

${ }^{92}$ Yamamoto (n 69) 67 discusses the necessity of co-operation between the courts and bar associations in the future. Also see Saibansho shoku'in sōgō kenshū jo (n 72) 32; Sato, 'Kanzai nin seido ni miru nichi doku chū no hikaku' (n 3) 52 .

${ }^{93}$ Interview (n 7) (28 November 2014). 
cases mean that it is easier for judges to keep track of the bengoshi who are likely to seek trustee work and their perceived appropriateness for a particular case. ${ }^{94}$ There are jurisdictions close to Tokyo with heavy caseloads that may also benefit from such training, however, which are not able to offer the training due to a lack of resources, including at the court. ${ }^{95}$ Therefore it is more difficult for courts in those jurisdictions to differentiate between potential trustees, and on-thejob-training remains key. Accordingly, it is likely that the courts in those jurisdictions will continue to award jobs to a small number of practitioners who themselves have the requisite job experience or are members of firms which do.

One practitioner interviewed for this article with approximately ten years of experience recalls undertaking the three one-hour long lectures required as part of the Tokyo training. ${ }^{96}$ The lectures are given by judges and specialist trustees and focus on practical matters. The interview with the practitioner also highlighted the on-the-job training he received as an associate in a large firm. ${ }^{97} \mathrm{He}$ undertakes smaller matters in his own right as a trustee, but also assists on larger insolvencies where his senior colleagues are appointed as trustee. One of the senior practitioners interviewed for this article noted that to the extent that a bengoshi hasn't received a trustee appointment in his or her own right, the court may still appoint that person after taking into consideration the firm at which they work and whether the person has worked with experienced practitioners on relevant matters. ${ }^{98}$ Accordingly, a lack of experience does not automatically preclude a candidate from acting as a trustee, but senior members of that candidate's firm will be expected by the court to mentor the candidate and ensure matters are handled appropriately.

As the Tokyo District Court began to internally formalise its approach to trustee appointment, it also simplified the work required of a bankruptcy trustee, making the work of trustees more attractive to more bengoshi. Ultimately, the Level 1 List was so full that there were not enough cases to allocate to all Level 1 bengoshi, and bengoshi began to complain. ${ }^{99}$ The Court discussed the issue with the relevant bar associations and announced that bengoshi with experience acting as a petitioning representative (mōshitate dairi'nin) in a bankruptcy proceeding would be given precedence amongst Level 1 bengoshi. ${ }^{100}$ The term mōshitate dairi'nin is widely used in Japan to refer to practitioners who assist debtors prior to filing and make a filing. ${ }^{101}$ As a result of the

94 Ibid.

${ }^{95}$ Ibid (2 December 2014).

${ }^{96}$ Ibid (27 November 2014).

${ }^{97}$ Ibid.

98 Ibid.

${ }^{99}$ Sonoo (n 9) 4.

${ }^{100}$ Ibid 5.

${ }^{101}$ These insolvency practitioners may continue to be involved after a proceeding is commenced, particularly where the company is being restructured as opposed to broken up and sold or wound up. Accordingly, Sato argues that the term is confusing and should be avoided, but he also acknowledges that the Japanese terminology is probably already so established that it is difficult to use another term in this context. See Sato, 'Mushō kōi hi'nin to sagai kōi hi'nin no kankei: dairi'nin no hōshū hi'nin jiken kara kangaeru' (n 3) 265. On this point, Sato also refers to 
announcement, those bengoshi seeking to become trustees worked hard at finding bankruptcy cases. $^{102}$

Practice at the Tokyo District Court in relation to the appointment of trustees continuously improved and eventually percolated throughout Japan's district court network. ${ }^{103}$ Sato, an academic from Chuo University in Tokyo, notes that the practice has developed whereby bengoshi with approximately three years' experience are eligible to take the course for potential trustees offered by the bar associations in Tokyo. ${ }^{104}$ Some courts also ask insolvency practitioners to complete an annual questionnaire on which they can indicate the type of work that they would like to do and their commitment levels, and provide information about their experience. ${ }^{105}$ The court then allocates comparatively easy cases to candidates until they work their way up to responsibility for complex cases. The increase in cases around 2000, however, made it impracticable for judges to closely supervise every aspect of every case and judges relied increasingly on the competence and experience of bengoshi acting as petitioning representatives and trustees. ${ }^{106}$ Unless there was a dispute between those bengoshi, the judges relied on the judgment of the bengoshi acting as trustee. ${ }^{107}$

The court's increasing reliance on the trustee-bengoshi reinforces the importance of the integrity of the List. On the rare occasion that a bengoshi-trustee acted inappropriately, that bengoshi would be struck from the List by a judge after consultation with colleagues. ${ }^{108}$ According to Sonoo, he sought to ensure that the process was fair for a bengoshi by requiring consultation with all 12 judges in the Division before taking action against a bengoshi, but the details of those consultations and reasons for the practitioner being struck off the List were not made public. ${ }^{109}$ The lack of public disclosure also means that potential private clients of the bengoshi are not privy to the matters leading to the bengoshi being struck off the List. Further, from the

commentary by Yuki Matsushita, 'Saisei saimusha dairi no chi'i ni kansuru ichi kōsatsu' (Consideration regarding the status of the rehabilitation debtor's representative) in Hiroshi Takahashi et al. (eds), Minji tetsuzuki no gendai teki shimei - Itō Makoto sensei koki shukuga ronbun shū (Current Mission of Civil Proceedings - Papers to Commemorate the Seventieth Birthday of Makoto Ito sensei) (Yuhikaku, Tokyo, 2015) 1069, 1071; Yuki Matsushita, 'Saikensha dairi'nin' (Debtors' representatives) (2015) 61 Minji Soshō Zasshi (Civil Litigation Magazine) 98. Matsushita refers to mōshitate dairi'nin as just dairi'nin (representatives).

${ }^{102}$ Sonoo (n 9) 4 argues that the process created a 'virtuous cycle' (kojjunkan).

${ }^{103}$ Ibid 5.

${ }^{104}$ Sato, 'Kanzai nin seido ni miru nichi doku chū no hikaku' (n 3) 52.

${ }^{105}$ Interview (n 7) (24 November 2014). The responses to the example questionnaire cited by the interviewee require the respondents to indicate their level of commitment, for example, 'definitely want to do this type of matter', 'will do it if assigned', and 'definitely don't want to do it'. Copy of questionnaire held by author.

${ }^{106}$ Sonoo (n 9) 4.

${ }^{107}$ Ibid 5.

${ }^{108}$ Ibid.

${ }^{109}$ Email from Sonoo to author (n 70). 
practitioner's perspective, the bengoshi does not have a right of appeal if they are struck off the List.

There is also no right for creditors to directly remove a trustee under the Japanese bankruptcy or corporate reorganisation proceedings; creditors have to apply to the court for a trustee's removal (BA Art 75(2), CorpRA Art 68(2)). The court must speak with the trustee before removing the trustee (BA Art 75(2), CorpRA Art 68(2)). Sonoo recalls a case of a trustee being removed by the court prior to the reforms for misappropriation from the bankruptcy estate, but the court took action before the creditors identified any issues. ${ }^{110}$ The court's approach is consistent with the applicable insolvency legislation which requires the court to supervise the trustee (BA Art 75(1), CorpRA Art 68(1)). Sonoo does not recall a case of a trustee being accused of misappropriation since the reforms in 2000 which led to shorter timeframes for proceedings. ${ }^{111}$ Further, the legislation requires the court to remove a trustee on the basis of poor performance of the trustee in the administration of the proceeding or disposition of property (BA Art 75(2), CorpRA Art 68(2)). Sonoo recalls applications by creditors for the removal of the trustee based on the creditors' own interests, but none were successful in proving to the court's satisfaction that the trustee's poor performance in this area justified removal. ${ }^{112}$

\section{E Appointment of so-called internal trustees in corporate reorganisation proceedings by the Tokyo District Court}

Tokyo District Court's innovative approach to insolvency practice in the 2000s also saw it experiment with the appointment of incumbent management and advisers as trustees on the commencement of a corporate reorganisation proceeding. Although the corporate reorganisation proceeding requires a trustee to be appointed, technically the law does not preclude these incumbent people from being appointed as trustees. DIP-style reforms included in the Civil Rehabilitation Act provided a blueprint for courts and practitioners in the context of these corporate reorganisations. Corporate reorganisation proceedings are typically larger, more complex and costly than civil rehabilitation proceedings, however. Further, one interviewee noted that there are many firms capable of handling bankruptcy matters, but only a few law firms with experience in corporate reorganisation matters. ${ }^{113}$ This observation is also consistent with the fact that few matters proceed as corporate reorganisations, and the vast majority of cases in Japan are civil rehabilitations or bankruptcy cases. Given the significance of corporate reorganisation cases, the Tokyo District Court also established a practice of requiring debtors and

\footnotetext{
${ }^{110}$ Ibid.

${ }^{111}$ Ibid.

${ }^{112}$ Ibid.

${ }^{113}$ Interview (n 7) (27 November 2014).
} 
their advisers to consult with the Court prior to filing a petition to commence a corporate reorganisation proceeding. ${ }^{114}$

The Tokyo District Court facilitated the first DIP-style reorganisation proceeding in 2009 by appointing the debtor's management as trustee. ${ }^{115}$ Chun and Ide set out the circumstances in which the court may consider such an appointment: no inference of wrongdoing by incumbent management; no objection by major creditors or any sponsor candidate; and the appointment will not compromise the 'fair operation' of the proceeding. ${ }^{116}$ Under this framework, the debtor may also continue to work with its existing corporate legal counsel, rather than a different bengoshi appointed by the court as trustee. In some cases, the court has chosen to appoint the incumbent bengoshi as the trustee. ${ }^{117}$

These so-called insider appointments are designed to increase the potential for a speedy resolution of the corporate reorganisation, because third parties don't have to be brought up to speed on the debtor's business. ${ }^{118}$ The appointment of insider trustees has been questioned by creditors and their advisers, however, who worry that they will not act as transparently or fairly as a court-appointed trustee. ${ }^{119}$ To counter-balance the debtor's new influence in proceedings, creditors were to be provided with more information and given greater involvement in proceedings under the reforms in the 2000s. ${ }^{120}$ Creditor concerns about the quasi-DIP corporate reorganisation of Spansion in 2009 led to the Tokyo District Court approving the first secured creditors' committee in Japan. ${ }^{121}$ The increasing reliance on DIP proceedings for both corporate reorganisation and civil rehabilitation proceedings, and the appointment of management and prepetition legal advisers as trustees, has also contributed to emerging concerns about pre-petitioner insolvency practitioner remuneration which is not directly supervised by the courts, as discussed below. ${ }^{122}$

\section{F Roles for courts in setting and reviewing remuneration of court-appointed insolvency practitioners in Japan}

\footnotetext{
${ }^{114}$ Sonoo (n 9) 2.

${ }^{115}$ Chun and Ide (n 6) 399.

116 Ibid 400.

${ }^{117}$ Ibid.

118 Ibid.

${ }^{119}$ Ibid 401.

${ }^{120}$ As discussed below, Sakai, a leading insolvency practitioner in Japan, argues that this aspect of the reforms has not gone far enough in practice, however. Sakai et al. (n 5).

${ }^{121}$ Chun and Ide (n 6) 401. In relation to the Spansion case generally, see Sakai et al. (n 5); Hideyuki Sakai and Taro Awataguchi, 'Shijō hatsu no kōsei tanposha i'inkai to sono igi - Spansion Japan no DIP gata kōsei tetsuzuki' (The First-Ever Secured Creditors' Committee and its Significance - Spansion Japan's DIP-Model Reorganisation Proceeding) (2011) 1918 Kinyū hōmu jijō (Financial Law Journal) 24.

122 Chun and Ide (n 6) 399.
} 
In addition to the courts' roles in appointing trustees in Japan, courts also play a significant role in setting and reviewing insolvency practitioner remuneration, including by applying internal rules and expectations to remuneration claims, and by way of setting fee schedules. This section considers the evolution of contemporary judicial attitudes towards remuneration and calculation standards, and also extends the article's focus to the development of fixed remuneration for supervisors (kantoku i'in) in civil rehabilitation proceedings at the turn of the 21 st Century. ${ }^{123}$ The case study based on remuneration of practitioners in civil rehabilitation cases demonstrates the significant involvement by courts in remunerating insolvency practitioners and keeping insolvency practitioner fees down.

A trustee's right to receive remuneration is guaranteed under law (BA Art 87, CorpRA Art 81). Details of the calculation methodology, however, are not set out in legislation. After a petition is filed and a trustee is appointed, a remuneration amount is determined by each district court based on each court's internal standards. Sato argues that the lack of legislative guidance gives the courts great flexibility when reviewing and setting remuneration, but as a consequence the calculation of insolvency remuneration in Japan is a black box. ${ }^{124}$ Flexibility may allow for differences in geographical and case-specific approaches, but it also makes comparisons between cases difficult, and discourages creditors from direct participation in the remuneration process. It also does not encourage market pricing or cost efficiencies. Given that many corporate workouts proceed informally, it is difficult to obtain complete data about the cost of insolvency in Japan, but it appears that it is not unusual for a court to discount a court-appointed practitioner's claim for remuneration. Japanese insolvency practitioners are also encouraged to be reasonable in their expense claims, because a court decides a practitioners' final remuneration as well as potentially their next formal appointment.

There have been public glimpses of court workings in relation to remuneration over the years. In an early discussion from 1967, the Tokyo District Court introduced its practice for determining a remuneration amount for a trustee. ${ }^{125}$ According to a report on the Court's practice, the court took the following steps to calculate remuneration in cases where the bankruptcy proceedings are completed with a distribution: assess the value of the bankruptcy estate collected by the trustee; calculate a 'standard amount of remuneration' by multiplying such estate value by a pre-fixed ratio; and ${ }^{126}$ make adjustments based on the actual situation considering the following related

\footnotetext{
${ }^{123}$ Because the Civil Rehabilitation Act was effective prior to the reforms to other insolvency legislation, innovations in practice at this time were often developed and formalized first under civil rehabilitation proceedings and then applied to future reformed proceedings.

${ }^{124}$ Sato, ‘Mushō kōi hi'nin to sagai kōi hi'nin no kankei: dairi'nin no hōshū hi'nin jiken kara kangaeru' (n 3) 277.

125 Junichi Furukawa, 'Hasan kanzai nin no hōshu kettei no jiki oyobi sono gaku' (Timing of remuneration determination for bankruptcy trustees and remuneration amount) (1967) 210 Hanrei Taimuzu (Hanrei Times) 88.

${ }^{126} \mathrm{Ibid} 90$. The ratio is generally higher (although it is suggested that it should never exceed 20 percent of the value of the bankruptcy estate) where the value of bankruptcy estate is lower, and the ratio decreases as the value of bankruptcy increases.
} 
factors: (a) degree of difficulty of the case; (b) diligence and performance of the trustee; (c) actual result of the case (that is, how long it took to deal with the case / how much the trustee was able to collect for the bankruptcy estate from his or her efforts, etc.); (d) to what extent the trustee influenced the work; (e) the number of trustees; (f) the balance of the amount and ratio of distribution and remuneration; and $(\mathrm{g})$ the general economic conditions, etc. ${ }^{127}$

As this English translation of the calculation method suggests, the method is open to interpretation and subjective application by an individual judge assigned to the relevant case. More recently, one of Japan's leading insolvency law scholars, Makoto Itō, argues that the size of the bankruptcy estate forms the fundamental driver for determining remuneration, with other factors such as the degree of difficulty of the case, the diligence of the trustee, and level of distribution to creditors, being considered in light of that key factor. ${ }^{128}$ Typically, the trustee receives a remuneration payment at the same time as distributions are made to creditors, including at the same time as any intermediate distribution. Depending on the case, however, the court may authorise an advance payment of an estimated remuneration amount. ${ }^{129}$ Sato also notes that the most important factor in establishing remuneration for a trustee today is the amount of the debtor's assets, with a passing consideration for the case's complexity and the practitioner's efforts. ${ }^{130}$

A case's complexity and the practitioner's efforts, however, may not be reflected in the value obtained from the assets. A trustee may be required to spend time and money where there is an environmental issue or dealing with the protection of private information such as client lists, for example. ${ }^{131}$ Another important consideration is the involvement of secured creditors and any benefit that they may receive from the trustee's efforts. Where secured property is necessary for continuing the operation of a business, for example, an insolvency practitioner may seek an agreement from secured creditors not to exercise their rights (betsujōken kyōtei) by, for example, arranging instalment payments. The insolvency practitioner may also seek court permission to extinguish a security interest (CivRA Art 148, BA Art 186), or seek a court order for a stay

\footnotetext{
${ }^{127}$ Furukawa (n 125) 89-93.

${ }^{128}$ Makoto Itoh, Hasanhō minji saiseihō (Bankruptcy Act and Civil Rehabilitation Act) (2nd sup, 2nd edition, Yūhikaku, 2011) 137, 142. This comment refers to Tokyo chisai hasan wagi jitsumu kenkyū kai (Tokyo District Court Study Group on Bankruptcy and Composition Practice) (ed), Hasan wagi no jitsumu (ue) (Practice of Bankruptcy and Composition (First vol)) (Minji hō jōhō sentaa, 1988), 92.

${ }^{129}$ Itoh (n 128).

${ }^{130}$ Sato, 'Kanzai nin seido ni miru nichi doku chū no hikaku' (n 3) 59.

${ }^{131}$ Tetsuo Sato, 'Hasan kanzai nin no hōshu ni kansuru shiten to ronten' (Point of View and Point of Discussion in relation to Remuneration for Bankruptcy Trustees) in Kanami shinichi taishoku kinen ronshu (Collection in Memory of Retirement of Shinichi Kanami) (Ritsumeikan Daigaku Hogakukai, forthcoming in 2017). For a discussion on a trustee's responsibility for the protection of private information, see Seiji Hashimoto, 'Cloud Computing jidai no tōsan to kanzai nin no sekinin futan no arikata ni kansuru ichikōsatsu — kojin jōhō hogo wo chūshin ni' (A Study of the Responsibilities of Trustees in the Cloud Computing Age: Focusing on Personal Data Protection) (2011) JPSJ SIG Technical Report 2001-DPS-148 No.2.
} 
(CivRA Art 31), or use these mechanisms, or the threat of their use, to encourage a secured creditor to support and participate in a formal proceeding. ${ }^{132}$ In such situations, the practitioner may become involved in negotiations about the secured collateral, however, how the practitioner is remunerated in relation to this work is not clear. ${ }^{133}$

At the same time as the Tokyo District Court introduced innovations in relation to appointing trustees in the 2000s, it also made efforts to reduce the cost of filing for bankruptcy and civil rehabilitation. ${ }^{134}$ Prior to 2000 , an individual debtor wishing to file for bankruptcy was required to pay JPY 500,000 into court as advance payment (yonokin), and the amount for a company was JPY 800,000. Further, if an individual debtor filed in conjunction with a company filing, which is often the case for small-medium companies where management are also owners, the debtors had to advance JPY 1,300,000 and an additional JPY 500,000 for every further individual. ${ }^{135}$ The yonōkin to be paid into court by a debtor is to cover expenses, including the court-appointed practitioner's remuneration. These amounts were high for a debtor in financial distress. Around 2000, the Tokyo District Court reduced the yonōkin amount for a small-scale bankruptcy proceeding with supervision by a trustee (shögaku kanzai jiken) to JPY 200,000 per filing. ${ }^{136}$

This small-scale bankruptcy proceeding was developed by the Tokyo District Court for companies and individuals who have some assets and are not eligible for an expedited proceeding which allows for an order terminating the bankruptcy proceeding at the same time as an order is made for its commencement (doji haishi). ${ }^{137}$ Not every district court offers the smallsscale proceeding, and each district court has its own rules as to the amount of yonōkin and the

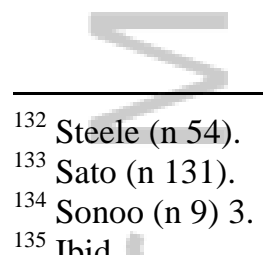

135 Ibid.

${ }^{136}$ In a shōgaku kanzai jiken, the appointed trustee is expected to perform routine tasks and thus remuneration of JPY 200,000, which is equal to the amount of yonōkin, is considered sufficient. Sato, 'Mushō kōi hi' nin to sagai kōi hi'nin no kankei: dairi’nin no hōshū hi'nin jiken kara kangaeru' (n 3) 277 and 279; Sato (n 131) 6; Sonoo (n 9) 4. Separate handling fees are required under provisions of the Act on Costs of Civil Procedure (Act No. 40 of 1971): JPY 20,000 if the creditor is filing the bankruptcy petition (Art 3 and the Appended Table 1, (12)), and JPY 1,000 if the debtor is filing the petition (Art 3 and the Appended Table 1, (16)), and an additional JPY 500 if the debtor is petitioning for a grant of discharge (Art 3(4) and Appended Table 1, (17)(e)). These fees are payable by revenue stamps. Tokyo District Court fees as at 2004 are listed by Ginza Seiwa Law Office: Ginza Seiwa Law Office, 'Hasan jiken no tetsuzuki hiyō ichiran', available at: <www.ginzaseiwa.jp/feature/feature05_01.pdf〉. Another law firm, LSC sōgō hōritsu jimusho, lists costs for filing and standard yonōkin based on the debt amount for insolvency matters at the Tokyo District Court: LSC sōgō hōritsu jimusho, 'Hōjin kaisha hasan no saiban hiyō, yonōkin', available at: < https://www.houjintousan.jp/hasan/hiyou/tokyo.html>.

${ }^{137}$ LSC sōgō hōritsu jimusho, 'Hasan tetsuzuki ni okeru shōgaku kanzai tetsuzuki to wa?', available at: <https://www.houjintousan.jp/hasan/kanzai/shougakukanzai.html>. See also the discussion below and at $\mathrm{n} 145$. 
requirements to qualify for the proceeding. ${ }^{138}$ No additional yonōkin was or is charged for individual debtors filing in relation to a corporate filing at the Tokyo District Court. ${ }^{139}$

These payments are designed to covered the final amount of remuneration in cases where there are no or nominal assets which were dealt with under a simplified bankruptcy procedure. ${ }^{140}$ These measures were taken after consultation and with the consent of the three bar associations in Tokyo. It is difficult to see, however, how the bar associations could resist the requests of the Tokyo District Court at the time given the Court's control over appointments and remuneration as outlined in this article and the difficult economic circumstances in Japan at the time which also encouraged bengoshi to look for new areas of practice. The Tokyo District Court was asked by the bar associations, Ministry of Economy, Trade and Industry and others to increase the relative payment bengoshi receive in real terms in return. The Court reduced the amount of work involved in a filing commensurate with the fee being charged and simplified the matters it required a trustee to undertake as part of his or her appointment. ${ }^{141}$

Today, many district courts publish their fees and yonōkin requirements and basic fee information is readily available to insolvency practitioners. Hiroshima District Court Main Branch lists its fees on the Internet, for example. ${ }^{142}$ Kyoto District Court $\left(5^{\text {th }}\right.$ Civil Division Bankruptcy Matters) published a number of guidance notes in a practitioner-oriented journal, including detailed information about yonōkin and remuneration claims. ${ }^{143}$ The current yonōkin for the Tokyo District Court for a bankruptcy proceeding involving a company is still a minimum of JPY 200,000 for a small matter with an additional amount of JPY 12,830 payable for any additional company. ${ }^{144}$ Takamatsu District Court in regional Japan lists the fees for bankruptcy proceedings, and provides for the situation where the yonokin may be reduced, which includes where it is expected that a high amount may be recovered from savings, an insurance

${ }^{138}$ Ibid.

${ }^{139}$ Sonoo (n 9) 4.

${ }^{140}$ Email from Takashi Sonoo to author (23 February 2016). Email on file with author. Cited with permission.

${ }^{141}$ Sonoo (n 9) 6.

${ }^{142}$ By way of further example, see Hiroshima District Court Main Branch, 'Kakushu jiken no mōshitate tetsuzuki ryō nado - ranhyō' (Schedule - Filing Procedural Fees etc. for All Matters), available at: <www.courts.go.jp/hiroshima/saiban/tetuzuki/tiho_tesuryoichiran/index.html>.

${ }^{143}$ Kyoto chihō saibansho dai 5 minjibu hasan gakari (Kyoto District Court (5th Civil Division Bankruptcy Section)), 5 Minyasu hasan jaanaru Vol. 1 (15 November 2013), Vol. 2 (2 December 2013), Vol. 3 (13 December 2013 ), Vol. 4 (25 December 2013), Vol. 5 (24 February 2014). These publications are distributed to the bengoshi practicing in this area through the Kyoto bengoshi kai (Kyoto Bengoshi Association). Volume 4 includes Attachment No. 2 which sets out the advance payment amounts for dojji haishi bankruptcy matters) (JPY 10,584), and individual rehabilitation (petition by a bengoshi representative is JPY 12,268 and petition by debtor or judicial scrivener is JPY $162,268)$.

${ }^{144}$ Tokyo District Court, 20th Civil Division, 'Hasan mōshitate yōryō oyobi kanzai jimu yōryō' (Bankruptcy Petition Outline and Bankruptcy Administration Outline), 18 May 2010. 
repayment, trust fund or accounts receivable. For a personal bankruptcy application combined with a petition for termination (doji haishi), the yonokkin may be even further reduced. ${ }^{145}$

Similar efforts have been made to reduce costs and thus remuneration in relation to civil rehabilitation proceedings. Prior to the introduction of the civil rehabilitation procedure, the calculation of yonōkin under its predecessor, the Composition Act (Act No. 72, 1922; Wagi hō), discouraged potential debtors from entering into formal proceedings. ${ }^{146}$ The costs were not well known and could change as the proceeding progressed if the court felt additional funds were required. ${ }^{147}$ The work required just to file a petition for composition was extensive and prohibitive for many small-medium enterprises. Civil rehabilitation procedure yonōkin costs are set on a sliding scale depending on the amount of the debtor's assets. During the reform process, bengoshi and financial institutions demanded predictability of costs ${ }^{148}$ and it was argued that supervisor and accountant remuneration should also be standardised. ${ }^{149}$ In a civil rehabilitation proceeding, the Tokyo District Court typically paid 50 percent of the yonokin to the supervisor (kantoku i'in), 30 percent to a certified accountant if appointed by the supervisor, and 20 percent was retained for costs in case the matter was transferred to bankruptcy. ${ }^{150}$

The current yonōkin scale for ordinary civil rehabilitation proceedings ranges from approximately JPY 1 million to JPY 13 million and above, depending on the jurisdiction and amount of debts (calculated based on debts of JPY 50 million and below to JPY 100 million and over respectively). ${ }^{151}$ According to empirical research in Japanese focusing on cases between 2000 and 2010, the most common range of yonōkin at the Tokyo District Court was between JPY 6 million and JPY 7 million (30 percent of cases), while the most common range at Osaka District Court (28 percent) and Sendai District Court (66.1 percent) was between JPY 3 million

\footnotetext{
145 The reduced payment covers the gazette notification, and the amount varies depending on the district court. Ginza Seiwa Law Office website lists the yonōkin for a doji haishi bankruptcy application for the Tokyo District Court as JPY 14,170: Ginza Seiwa Law Office (n 136). Takamatsu District Court lists yonōkin for a dōji haishi bankruptcy application as JPY 10,584: Takamatsu chihō saibansho, 'Hasan tetsuzuki kaishi mōshitate jiken ni kansuru yonōkin tō kijun hyō' (Courts in Japan), available at: <www.courts.go.jp/takamatsu/vcms_lf/20140303001-1.pdf>. Niigata District Court sets the yonōkin at JPY 10,290: Niigata District Court, 'Jiko hasan mōshitate ni tsuite' (Courts in Japan), available at: <http://www.courts.go.jp/niigata/saiban/tetuzuki/zikohasan/>. LSC sōgō hōritsu jimusho website (n 137) notes that it is rare for a company to be successful in receiving an order for $d \overline{o j i}$ haishi at the same time as receiving a commencement order.

${ }^{146}$ Sonoo (n 9) 5.

${ }^{147}$ Sonoo et al. (n 8) 211.

148 Ibid 212

${ }^{149}$ See Uezu (n 47) 74, which refers to Yoshimitsu Aoyama (ed), Wagi hō no Jisshō teki kenkyū \{Empirical Research on Composition Law) (Shōji hōmu, Tokyo, 1998) 146.

${ }^{150}$ Sonoo (n 9) 6.

${ }^{151}$ Sonoo et al. (n 8) 212; Uezu (n 47) 71.
} 
and JPY 4 million. ${ }^{152}$ At Naha District Court, the most common range was JPY 4 million and JPY 5 million (31.8 percent). ${ }^{153}$

The higher amounts for filings in the Tokyo District Court most likely reflect the higher amount of debt associated with entities filing in that jurisdiction. ${ }^{154}$ It may also reflect the greater complexity and size of those debtors. The higher initial amounts may also reduce the possibility that an additional payment will be requested by an insolvency practitioner and therefore need to be calculated by a court. Payments over and above the initial yonōkin were not required in most cases analysed by researchers at the Tokyo District Court (68.2 percent), Sendai District Court (66.1 percent) and Naha District Court (75 percent). Additional payments were required in 60.2 percent of the cases analysed from the Osaka District Court. ${ }^{155}$ Different amounts may also be charged depending on whether a debtor is represented by a bengoshi or a judicial scrivener, or is self-represented. A court typically requires a higher yonōkin if no bengoshi is involved, thus encouraging debtors to use bengoshi. ${ }^{156}$ Where a civil rehabilitation proceeding is terminated and transferred to a bankruptcy proceeding, there is unlikely to be much of the yonōkin moneys left. No matter how well the trustee monetizes any remaining assets, the proceeds may not be enough to cover costs. ${ }^{157}$ The trustee's best opportunity to be paid in such circumstances in a corporate case is to sell the company as a going concern as quickly as possible. ${ }^{158}$

\section{G Consequences of lower remuneration for insolvency practitioners in Japan}

The extent to which trustees in bankruptcy and corporate reorganisation cases or supervisors in civil rehabilitation cases are able to cover their costs based on the courts' determinations and fee schedules in Japan is not clear. ${ }^{159}$ Japan's system for resolving insolvency again ranked number

\footnotetext{
${ }^{152}$ Uezu (n 47) 70.

${ }^{153}$ Ibid.

${ }^{154}$ Ibid 69-73.
}

${ }^{155}$ Ibid 73. The Osaka District Court appears to prefer charging a lower yonōkin amount, and adjusting the overall payment once the rehabilitation plan is approved.

${ }^{156}$ The Sapporo District Court, for example, requires a higher advance payment (JPY 311,928) unless a bengoshi representative assists with the petition (JPY 11,928): Sapporo District Court, 'Kojin saisei tetsuzuki ni kansuru Q\&A' (Courts in Japan), available at:

<www.courts.go.jp/sapporo/saiban/tetuzuki_tisai/kozin_saisei_tetuzuki/index.html>. See similarly, Tottori District Court, 'Kojin saisei tetsuzuki ni kansuru Q\&A' (Courts in Japan), available at: <www.courts.go.jp/tottori/saiban/tetuzuki/kojin/index.html>.

${ }^{157}$ Most of the 25.4 percent of civil rehabilitation cases studied from the Sendai District Court which did not provide any refund of the advance payment at completion, were cases that were transferred to bankruptcy from civil rehabilitation. The researchers assumed that the remainder of any advance payment at the time of transfer to the bankruptcy proceeding was then used to pay the remuneration of the bankruptcy trustee. See also Uezu (n 47) 76.

${ }^{158}$ Ibid.

${ }^{159}$ Empirical research from Australia suggests that there are typically no assets available to fund remuneration in official liquidations. Phillips found that, '(I)n respect of assetless official liquidations (realisable assets of [AUD] 0 to [AUD] 10,000), the recovery rates for the Official Liquidators' remuneration and disbursements were $2 \%$ and 
two in the World Bank Group's Doing Business 2016, partly as a result of the criteria which gives credit for lower costs. ${ }^{160}$ The cost of resolving insolvency is substantially cheaper in Japan than the average cost in OECD high income countries according to the World Bank (see Table 1).

Table 1: World Bank Doing Business Resolving Insolvency Cost of Insolvency Rankings (extract) ${ }^{161}$

\begin{tabular}{|l|l|l|l|l|l|l|l|l|}
\hline & Singapore & Japan & $\begin{array}{l}\text { Hong } \\
\text { Kong }\end{array}$ & $\begin{array}{l}\text { United } \\
\text { Kingdom }\end{array}$ & Canada & $\begin{array}{l}\text { Australia } \\
\text { Germany } \\
\text { Germated }\end{array}$ & $\begin{array}{l}\text { OECD } \\
\text { States } \\
\text { high } \\
\text { income }\end{array}$ \\
\hline $\begin{array}{l}\text { Cost }(\% \\
\text { of estate })\end{array}$ & 3 & 3.5 & 5 & 6 & 7 & 8 & 8.2 & 9 \\
\hline
\end{tabular}

In addition to the control and influence over remuneration which the courts have, the perceived cheapness of resolving Japanese insolvencies may also reflect overall low bengoshi and professional charge out rates in Japan. The JFBA published a schedule of fees until March 2004. ${ }^{162}$ The schedule was abandoned due to concerns that it was anti-competitive, but anecdotal evidence suggests that it is still used as a guide by many bengoshi when setting their own fees. The schedule provides that the basic charge out rate of a bengoshi should be between JPY 5,000 and JPY 10,000 for each half hour of an initial consultation for individuals, and between JPY 5,000 and JPY 25,000 for each half hour of a general consultation. ${ }^{163}$ Fees for providing an expert opinion in writing were set at between JPY 100,000 and JPY 300,000 in a noncomplicated matter.

For bankruptcy matters, the schedule suggested a retainer for a personal bankruptcy of a nonbusiness owner from JPY 200,000, and a retainer for a personal bankruptcy of a business owner or non-personal bankruptcy from JPY 500,000. ${ }^{164}$ It also suggested a retainer for a company workout and special workout matter from JPY 1 million, and a retainer for a corporate reorganisation matter from JPY 2 million. The final remuneration should be calculated on the basis of economic benefit of the case (jiken no keizaiteki na rieki), according to the schedule. ${ }^{165}$

12\% respectively'. See Amanda Phillips, 'An Analysis of Official Liquidations in Australia' (2012 IPA Terry Taylor Scholarship Report, 2013), 3.

${ }^{160}$ Doing Business, 'Doing Business 2016: Measuring Regulatory Quality and Efficiency' (World Bank Group, 27 October 2015), available at: 〈www.doingbusiness.org/reports/global-reports/doing-business-2016>. Finland was ranked first. For a critique of the survey, see Gerard McCormack, 'World Bank Doing Business Project: Should Insolvency Bengoshi Take it Seriously?' (2015) 28(8) Insolvency Intelligence 119-123.

${ }^{161}$ Doing Business, 'Resolving Insolvency' (World Bank Group), available at: <www.doingbusiness.org/data/exploretopics/resolving-insolvency>.

${ }^{162}$ For a copy of the historical fee schedule, see Miyazaki Bar Association, '(Kyū) nihon bengoshi rengōkai hōshū tsū kijun', available at: <www.miyaben.jp/consultation/pdf/expenses_kijun.pdf >.

${ }^{163}$ Ibid.

${ }^{164}$ Ibid.

${ }^{165}$ Ibid. For matters with an economic benefit of up to JPY 3 million, it suggested remuneration be set at 16 percent of the economic benefit. For the matters with an economic benefit from JPY 3,000,001 to JPY 30 million, it suggested remuneration be set at 10 percent of the economic benefit plus JPY 1,800,000. For matters with economic 
Civil rehabilitation matters should be charged on the basis of a retainer of JPY 1 million for a business owner; a retainer of JPY 300,000 for a non-business operator and a retainer of JPY 200,000 for small-scale individual rehabilitations and rehabilitations involving salaried debtors under the JFBA guidelines. The calculation of remuneration is essentially similar for bankruptcy matters.

Another explanation for insolvency practitioner rates in Japan which are lower than other OECD countries according to the World Bank's analysis is that secured creditors, typically financial institutions, exercise significant influence over market pricing which keeps costs down. Notably, the estimated costs are based on the World Bank's hypothetical scenario involving an insolvency with a secured creditor which the Japanese contributors assume will proceed as a civil rehabilitation case in Japan. Similarly, Dickfos argues that the market for professional insolvency services is bifurcated in Australia and the United Kingdom, and secured creditors receive a better rate from professional insolvency advisers. ${ }^{166}$ The influence of unsecured creditors is weak, however, and their capacity to supervise practitioners is not as great as if the practitioner were acting for the secured creditor. One possible result is that unsecured creditors pay more through the insolvency process. Moreover, secured creditors may enforce outside both bankruptcy and civil rehabilitation proceedings in Japan. Sympathy for unsecured creditors and the possibility of market failure in relation to practitioner fees cannot entirely explain developments in Japan, however. A key driver for the reforms in the Tokyo District Court in the 2000s was encouraging debtors to file for formal insolvency by keeping the immediate costs down. The courts were also part of a movement to build a pool of reputable and competent insolvency practitioners to assist with an increased volume of cases.

Creditors have a right to object to a remuneration ruling by a court (sokuji kōkoku, immediate $k \bar{o} k o k u$ appeal) and some creditors file objections (CorpRA Art 81(4), BA Art 87(2), CivRA 61(4)). Sonoo is not aware, however, of any objections being successful during his time at the Tokyo District Court. ${ }^{167}$ A remuneration determination involves a high level of discretion (sairyōsei no takai) and is not lightly reviewed. ${ }^{168}$ Further, in making the remuneration determination a court may have already examined and discounted a practitioner's claim. For example, Dr Takagi recollected that the court discounted his claim for approximately JPY 100 million by about ten percent when he acted as trustee for Kyoei Insurance in 2000, despite the

benefit from JPY 30,000,001 to JPY 300 million, it suggested remuneration be set at 6 percent of the economic benefit plus JPY 1,380,000. For matters with economic benefit higher than JPY 300 million, it suggested remuneration be set at 4 percent of the economic benefit plus JPY 7,380,000.

${ }^{166}$ See Jennifer Dickfos, 'The Costs and Benefits of Regulating the Market for Corporate Insolvency Practitioner Remuneration' (2016) 25 International Insolvency Review 56, 65.

${ }^{167}$ Email from Sonoo to author (n 70).

${ }^{168}$ Ibid. 
case being the biggest ever insolvency in Japan up until that point and involving ten deputy trustees over a period of six months. ${ }^{169}$

Insolvency can still be lucrative work in Japan, however. The final amount of remuneration will often not be clear at the outset, because a court-appointed trustee may have a claim for costs against the bankruptcy estate and thus receive distributions as the debtor's assets are realised in addition to the amount advanced into court at the time of filing. The opportunity for a trustee to claim a percentage from the proceeds that they help to realize for the bankruptcy estate arguably incentivises the trustee to ensure all assets are discovered and monetized. ${ }^{170}$ Those distributions are controlled by the judge in charge of the case. Corporate reorganisation proceedings are likely to be better paying for trustees who may receive up to JPY 1 billion, although most cases fall between the range of JPY 20 million and JPY 50 million. ${ }^{171}$

\section{H Court responses to new developments: remuneration of pre-petition insolvency practitioners and increasing informal workouts}

The reforms to Japanese insolvency law in the late 1990s and early 2000s encouraged individual and corporate debtors to seek advice prior to filing a petition. Individuals are charged a lower filing fee if they have legal representation, for example, and the introduction of business transfer provisions into the civil rehabilitation procedure facilitated pre-package filings where most of the advisory and negotiating work is concluded prior to filing a formal petition. Further, the number of informal workouts which have no court involvement is increasing. Whilst these developments may suggest that debtors, creditors and practitioners may have greater freedom to decide remuneration, the Japanese court's influence is still relevant in this context. First, Japanese courts may be asked to review remuneration paid to mōshitate dairi'nin or so-called petitioning representatives. Secondly, the practitioners act in the shadow of the court's power to appoint her or him as a trustee or supervisor on future cases and a court's ability to strike a practitioner of its List.

There have been at least five decisions involving a challenge by the court-appointed trustee to the remuneration paid to the debtor's representatives on the basis that the excessive portion of

\footnotetext{
${ }^{169}$ Interview with Dr Shinjiro Takagi (n 14).

${ }^{170}$ Hiroaki Tominaga, 'Hasan mōshitate no hōshū no sadame ni kansuru ryūi jikō' (Consideration of the rule of remuneration for bankruptcy petition) (2012) 63(1) Jiȳ to Seigi (Freedom and Justice) 20. Sonoo notes that the amount of remuneration is calculated on the basis of the value of the assets realised not on the amount available for distribution to creditors. He suggests that if the amount of assets is not large, the trustee might be allocated remuneration of about ten percent, but if the amount of assets is large, then the court might limit the amount of remuneration to three percent. The court will also take into account the level of effort required from the trustee in finding and monetizing assets, including complex litigation. Email from Sonoo to author (n 140). Email on file with author. Cited with permission.

${ }^{171}$ Interview (n 7) (27 November 2014).
} 
the remuneration was a voidable transaction. ${ }^{172}$ The small amounts at issue in the cases once again suggest the modest nature of practitioner remuneration in Japan. ${ }^{173}$ One of the cases from the Tokyo District Court (14 October 2010) suggests that the court's calculation process and considerations discussed above in relation to court-appointed trustee remuneration will also be applied to pre-petition remuneration. ${ }^{174}$ The case is also important because it shows how Japanese courts may extend their capacity to review insolvency practitioner remuneration beyond those cases where the practitioner is appointed by the court. The case in 2010 involved a bengoshi appointed to prepare a petition for the commencement of a bankruptcy proceeding. The main issue in the case was remuneration and the court ordered the return of part of the bengoshi fee.

In January 2009, the company and the bengoshi executed an engagement agreement under which the bengoshi was to complete all necessary work relating to a petition for commencement of a bankruptcy proceeding, including filing required documents, and the company was to pay JPY $1,890,000{ }^{175}$ In May, the company agreed to increase the payment to the bengoshi to JPY $2,940,000{ }^{176}$ At the time of execution of the engagement agreement, the bengoshi was required to deal with the creditors and landlords of the company, whereas the company was supposed to complete other necessary work, including the sale of movable property under the direction of the bengoshi. The bengoshi claimed to have dealt with lease companies and creditors of the company; confirmed the labour management of the company; collected a part of accounts receivable; drafted necessary legal documents in relation to the sale of inventory; and completed other work necessary for the filing of the petition to commence bankruptcy. ${ }^{177}$ The bengoshi did

\footnotetext{
${ }^{172}$ See Sato, 'Mushō kōi hi'nin to sagai kōi hi’nin no kankei: dairi'nin no hōshū hi'nin jiken kara kangaeru' (n 3) 266-271. The cases were from 1997, 2007, 2010, 2011 and 2014. Sato's article focuses on the treatment of the additional amounts as either a fraudulent voidable act or a gratuitous voidable act under articles 160-1 and 160-3 of the Bankruptcy Act respectively. A review of the Japanese literature and case law for this article did not reveal any additional cases.

${ }^{173}$ Ibid. The amounts at issue were between JPY 310,000 and JPY 5 million. Research in Australia found that court cases dealing with remuneration typically involve larger amounts: Steele, Chen and Ramsay (n 1).

${ }^{174}$ Tokyo Chihō Saibansho (Tokyo District Court) Oct. 14, 2010, hei 21 (wa) no 35331, Hanrei Taimuzu 2011: 1340:83. Also see Tominaga (n 170); Hideaki Sudo, 'Tōsan shori to bengoshi rinri no kihonteki shiza' (Insolvency Process and the Basic Standpoint of Bengoshi Ethics) in Nihon bengoshi rengōkai tōsan hōsei kentō i'inkai (Japan Federation of Bar Associations Bankruptcy Law Study Committee) (eds), Tōsan shori to Bengoshi rinri: Hasan, saisei jiken ni okeru rinri no jyunshu to bengo kago no bōshi' (Insolvency Process and Bengoshi Ethics: Ethics Compliance and Protection of Malpractice of Bengoshi in Bankruptcy and Rehabilitation Proceedings) (Kinyū Zaisei Jigyō Kenkyū sho, Tokyo, 2013) 2, 8; Yoichi Onishi, 'Adiire hōritsu jimusho ni 168 man en henkan meirei = bengoshi hōshū torisugi - Tokyo chisai' (Adire Law Office ordered to return 1,680,000 yen = Excessive Bengoshi's Remuneration - Tokyo District Court) 14 October 2010, Ichinichi isshō - bengoshi Onishi Yoichi no burogu (One Day One Life - Blog by a Bengoshi, Yoichi Onishi), available at: <http://ameblo.jp/onishiyoichi/entry10680443523.html>.

${ }^{175}$ Tokyo chihō saibansho (Tokyo District Court) Oct. 14, 2010, hei 21 (wa) no 35331, 2.

176 Ibid.

${ }^{177}$ Ibid 7.
} 
not visit the company's office, and only gave instructions to the company over the phone or by emails through judicial scriveners (shiho shoshi). The use of judicial scriveners and paralegals may also be another way in which insolvency practitioners in Japan keep costs down for small matters.

Further, in this case, it was the company who did the actual work at its office, including servicing creditors, sales of inventory, moving out of the office building, calculation of severance pay and dealing with insurances. ${ }^{178}$ To the extent that assets were sold, the bengoshi did not confirm any sale price in advance and only received reports from the company after it sold its own assets. ${ }^{179}$ Despite the bengoshi telling the company that he planned to file a petition in April 2009 at the latest, it was late in March when he started his examination and it was not until the beginning of May before he completed the necessary investigations for the petition. ${ }^{180}$ At the time of the petition, the company had 26 creditors with a total debt amount of JPY 46,895,571. ${ }^{181}$ At the time of the statement of approval or objection by the bankruptcy trustee, the number of the creditors was 16 and the total amount of debt was JPY 45,702,995. ${ }^{182}$

The plaintiff in this case, the bankruptcy trustee, argued that a fair remuneration amount for the work done was JPY 630,000 based on the remuneration guidelines for bengoshi provided by the JFBA and a reasonable balance with the work entrusted to the bengoshi. ${ }^{183}$ The trustee also argued that advertising expenses and the efforts of the bengoshi to monetize assets and debts before filing the petition should not be considered as grounds for remuneration. ${ }^{184}$ The defendant bengoshi in the case countered that in principle the remuneration amount should be decided freely based on the agreement between the parties to the extent that the amount is fair and in accordance with the facts. Because the bengoshi completed all the necessary work for a petition within an appropriate time, JPY 2,940,000 as agreed by the parties was an appropriate amount. ${ }^{185}$

The court found that notwithstanding the agreement between parties, remuneration must reflect the service provided by the bengoshi and any amount which exceeds a reasonable balance with the work may be set aside by a trustee. ${ }^{186}$ The court based its calculation of the remuneration amount for the bengoshi on the remuneration guidelines prepared by the JFBA, and noted that factors to be considered included: the economic benefit that the debtor received, the degree of difficulty of the case, the necessary time and work for the bengoshi to process the petition, and

\footnotetext{
${ }^{178}$ Ibid 8.

${ }^{179}$ Ibid.

${ }^{180}$ Ibid.

${ }^{181}$ Ibid.

${ }^{182}$ Ibid.

${ }^{183}$ Ibid 2-3.

${ }^{184}$ Ibid 3.

${ }^{185}$ Ibid 5.

${ }^{186}$ Ibid 8.
} 
other relevant factors. ${ }^{187}$ The court noted that other relevant factors may include maintenance costs for the bengoshi's firm such as advertising expenses, but these are only secondary factors with limited importance in any calculation of remuneration. ${ }^{188}$ The court also noted that the primary role of a bengoshi engaged to file a bankruptcy petition is to file the petition as soon as possible whilst also maintaining the bankruptcy estate of the debtor and it was inappropriate for this bengoshi to attempt to monetize debts in the absence of special circumstances, because this was the trustee's role post-commencement of the proceeding. ${ }^{189}$ The court found that the appropriateness of the work undertaken by the bengoshi should also be taken into consideration when deciding the bengoshi's remuneration. ${ }^{190}$

The court concluded that a fair remuneration amount in this case was JPY 1,260,000. First, the case was not particularly large or difficult, and the bengoshi did not make significant efforts to maintain the company's assets. ${ }^{191}$ The bengoshi completed and filed the petition, but the court found that the bengoshi had also conducted sales of the company's movable property which was a meaningless act for the creditors and there was no reason that they had to be sold prior to the petition; partly sold assets in an inappropriate manner; and thoughtlessly gave instructions with respect to selling some of the company's assets. ${ }^{192}$ Furthermore, a large part of the necessary work was conducted by the company itself, the bengoshi never visited the company's office, he only gave necessary instructions through judicial scriveners, and it was only once he was entrusted to file the petition that the bengoshi met with the company representatives. The court also found that the bengoshi gave priority to monetizing assets over filing the petition as requested by the company for the purpose of receiving a higher remuneration. The 2010 case illustrates that the courts will take a number of factors into account when calculating remuneration, including the ethical and professional conduct of the bengoshi.

Tominaga, a bengoshi, argues that the takeaway from such cases is that despite showing respect for the bargain struck between the parties over remuneration, the court may find a retainer payment or other remuneration paid to a bengoshi prior to a debtor's filing void as a preference if the pre-filing payment is found to be unreasonable. ${ }^{193}$ Tominaga argues that the relationship between a bengoshi and his or her client is based on good faith (shingi seijitsu). Accordingly, he argues that a bengoshi is not free to charge whatever amount she or he desires. The bengoshi must take into account the matter's complexity, the anticipated effort and hours required, and the

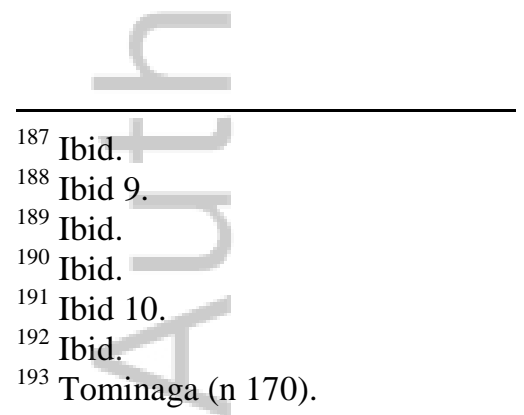


JFBA's schedule of charge out rates, although he notes that these no longer officially apply. ${ }^{194}$ His suggestions for issues that bengoshi and potential clients should take into account when appointing a pre-petition bengoshi to avoid payments being clawed back appear in Jiyu to seigi, the official journal of the JFBA. The publication of this type of Q\&A article suggests the interest that the JFBA also has in the topic of pre-filing practitioner remuneration.

The case is also interesting because it was prosecuted by the incoming bankruptcy trustee, suggesting a role in the regulation of insolvency practitioners generally by insolvency practitioners themselves. The Bankruptcy Act gives the trustee standing to sue and be sued (BA Art 80) and rights of avoidance (BA Art 160(1)). Sato argues that one way of dealing with prepetition insolvency practitioner remuneration is to require the practitioner to disclose all remuneration to any subsequent court-appointed trustee. ${ }^{195}$ Such a procedure would give the trustee an opportunity to review the remuneration for its reasonableness and challenge any inappropriate payments. It would also avoid the court becoming bogged down in reviewing prepetition remuneration payments, which Sato notes judges probably don't have an appetite or the resources to undertake in any event. ${ }^{196}$

There is a certain conflict in a trustee having the power to review a pre-petition practitioner's remuneration, however, because the court-appointed trustee may benefit from any remuneration repaid by the pre-petition insolvency practitioner. The recovered money may be used to pay the court-appointed trustee. Given the small amounts involved in the 2010 case and other cases analysed by Sato, however, it may also be the case that there isn't even enough to cover the expenses of the litigation relating to the exercise of the trustee's power of avoidance. Recent reforms in Australia to provide for the appointment of a third-party, independent registered insolvency practitioner to review remuneration may be one way to mitigate any perceived conflict. ${ }^{197}$ Japanese courts could also use court clerks in the same way that Australian courts have used registrars and cost assessors in relation to insolvency practitioner and legal practitioner remuneration respectively. ${ }^{198}$

\footnotetext{
${ }^{194}$ The JFBA withdrew its schedule of rates for bengoshi in March 2004 on the basis that the schedule was anticompetitive as discussed above. Sato also notes that the schedule is still used by many law firms despite the withdrawal: Sato, 'Mushō kōi hi' nin to sagai kōi hi'nin no kankei: dairi'nin no hōshū hi'nin jiken kara kangaeru' (n 3).

${ }^{195}$ Sato, 'Mushō kōi hi'nin to sagai kōi hi’nin no kankei: dairi’nin no hōshū hi'nin jiken kara kangaeru' (n 3) 15.

${ }^{196}$ Ibid.

${ }^{197}$ The Australian system was not in force at the time of writing. It has already been criticized, including because it will typically require the reviewing liquidator to be paid for out of the company's assets and the potential for practitioners to be reluctant to review or amend other practitioner's remuneration. See the discussion in Steele, Chen and Ramsay (n 1).

${ }^{198}$ Ibid.
} 


\section{Appointment and remuneration: future innovations and domestic criticisms}

The insolvency practitioner profession and the roles that courts play in their appointment and remuneration may be at a turning point in Japan. Asset-less and small-scale insolvencies remain relatively inexpensive based on the courts' fixed-fee schedules. Despite tight margins, Japanese insolvency practitioners still compete for trustee work; although the decrease in formal filings suggest that some of the skills, experience and knowledge built up over the last two decades may be lost, especially in relation to the civil rehabilitation procedure. Successful practitioners use the publicity and profile generated by court appointments to obtain other work which is more profitable, including, for example, acting for financial institutions or debtors in financial difficulties who are willing to pay higher rates or receiving appointments on corporate reorganisation cases. In this way, the better paying complex matters may be subsidizing smaller cases. $^{199}$

Other developments in Japan may lead to a decrease in the relative cheapness of Japanese insolvency proceedings in future, however. As more turnaround experts and distressed asset investors are becoming involved in insolvency matters in Japan, the sophistication with which these matters are being resolved has increased, which may also increase overall costs. ${ }^{200}$ Because fewer formal cases being filed, it is harder for practitioners in this market to compete on the basis of volume. ${ }^{201}$ Recent large-scale insolvencies have also used informal workout methods, at least in the first instance, making it harder for courts to directly exercise control over remuneration. Further, large law firms in Japan are also developing insolvency practices to work on these largescale restructurings, which was unheard of in the 1990s. ${ }^{202}$ They may seek to increase fees to sustain their business models. Higher fees and more profitable work may lead to less reliance on the courts for court-appointed work and further open up the restructuring industry to new players and industry-driven innovation.

There are also calls for change from inside Japan, including demands to take the interests of creditors into account more explicitly. Sakai argues for further reforms to provide greater transparency for creditors and increased roles for practitioners other than those people acting as trustees. ${ }^{203}$ Sakai's forceful account of the changes in insolvency practice in Japan over the last decade reflects his participation in several high profile insolvencies, including his role acting for

\footnotetext{
${ }^{199}$ On the Australian situation, see Phillips (n 159), who argues that these cross-subsidiaries exist in Australia.

${ }^{200}$ On innovation and suggestions for change in Japan, see Sakai et al. (n 5).

${ }^{201}$ Courts in Japan, 'Dai 2 bu Jiken no Tōkei' (n 24).

${ }^{202}$ Note, for example, the appointment of former judge Takashi Sonoo Esq. at Nishimura \& Asahi, and Hideyuki Sakai Esq. at Anderson Mori.

${ }^{203}$ Sakai et al. (n 5).
} 
the first-ever secured creditors' committee in Japan in the Spansion Case in $2009-10 .{ }^{204}$ Sakai's suggestions for reform generally take a creditor perspective, and are a reaction to some extent to the new standardised proceeding and cheaper fees instigated in the early 21 st century by the Tokyo District Court. Sakai describes what he perceives as the closed-shop surrounding Japanese insolvency proceedings:

court hearings are not common in Japanese insolvency proceedings. In practice, cases are often advanced via private communications among court appointed professionals... These professionals are routinely permitted ex parte communications with the court to shape the direction of a case...

Japanese court dockets are not available to the general public but only to parties with an interest in the case (or their bengoshi who have filed a power of attorney with the court). ${ }^{205}$

According to Sakai, the Japanese court has traditionally excluded creditors who have little capacity to influence proceedings. ${ }^{206} \mathrm{He}$ argues in favour of increased information being provided to creditors.

Increased transparency in the relationships between court-appointed insolvency practitioners may also provide other stakeholders, particularly creditors and their advisors, an opportunity to supervise and influence proceedings. Research from the United States suggests that creditor control does not eliminate "the fundamental inefficiency of the bankruptcy process", however. ${ }^{207}$ Ayotte and Morrison argue that whether to sell or reorganize is ultimately determined by the highest return to the class of creditors in control. Moreover, experience from the United Kingdom suggests that control does not necessarily impact payouts. ${ }^{208}$ Reforms in 2002 were designed to lessen the impact of secured creditor control in bankruptcy by abolishing a secured creditor's right to appoint a receiver. Under the new regime, the administrator has fiduciary

${ }^{204}$ On the Spansion case, see Sakai and Awataguchi (n 121). See also Hideyuki Sakai and Yukari Murayama 'Shinka suru tōsan tetsuzuki to M\&A no yūgō - kokusaika wo keiki toshite' (Sophistication of Insolvency Proceedings and M\&As - In the Wake of Globalisation) (2009) 9(6) Bijinesu Hōmu (Business Law) 46-52.

${ }^{205}$ Hideyuki Sakai, 'Overview of the Japanese Legal Framework to resolve a Systematically Important Financial Institution in Insolvency Proceedings in Japan' (International Insolvency Institute Twelfth Annual International Insolvency Conference, Supreme Court of France 2012), 5-6, available at:

<http://iiiglobal.org/component/jdownloads/viewdownload/152/5963.html>.

${ }^{206}$ Despite increasing creditor participation being one of the goals of the most recent reforms, Sakai argues that creditors are still fighting for recognition in Japanese formal proceedings: Sakai et al. (n 5).

${ }^{207}$ Kenneth Ayotte and Edward Morrison, 'Creditor Control and Conflict in Chapter 11' (2009) 1 J. Legal Analysis 511, available at: < http://scholarship.law.berkeley.edu/facpubs/2457/>.

${ }^{208}$ See John Armour et al., 'The Costs and Benefits of Secured Creditors Control in Bankruptcy: Evidence From The UK' (1st Annual Conference on Empirical Legal Studies Paper; University of Cambridge Centre for Business Research Working Paper No. 332, March 2009), available at:

$<$ https://papers.ssrn.com/sol3/papers.cfm?abstract_id=912302>. 
duties to all creditors. The research suggests that gross realizations since the reforms have increased, but this result has not changed outcomes for unsecured creditors, because direct bankruptcy costs, such as professional fees, concomitantly increased. ${ }^{209}$

Regardless of who controls the proceedings, however, changes in Japan to the institutional, organizational and industry contexts in which insolvency practitioners operate require a more transparent approach to appointing trustees and supervisors in future. Judges in Japan are transferred regularly throughout their careers; typically every three years. It is difficult for many of them to develop a speciality in insolvency law, and many rely heavily on practitioners and court clerks for the daily operation of cases and procedural matters. It is the job of the court clerks, for example, to put together a list of suggested candidates to be appointed as trustee for the judge's consideration. ${ }^{210}$ The court clerks also maintain the List. ${ }^{211}$ Traditionally, the small number of judges and bengoshi in Japan gave judges and court clerks some capacity to know, or at least know of, the bengoshi who come before them, despite regular transfers. Recent reforms to legal education leading to a dramatic increase in bengoshi numbers, albeit from a low base, also make it more difficult to track who, for example, is 'good' or 'appropriate' from the lists of aspiring trustees maintained by district courts. The increase in bengoshi numbers is also reflected in the large number of candidates who take the training course for admission to Level 1 of the Tokyo District Court's List. In future, there may need to be a new focus on ex post facto supervision of insolvency practitioners benchmarked against clear and publicly disclosed rules which provide more transparency for both insolvency practitioners and other stakeholders such as creditors.

Concerns about pre-petition insolvency practitioner remuneration in Japan and the appointment of management or pre-petition advisers as trustees also suggest that the previous system of detailed court involvement in cases supported by a small professional industry may not be a sustainable model for all cases in the future. The old model appears to have supported ethical behaviour by practitioners even if it did not support creditor involvement. Unsecured creditors relied on the courts and trustees to act impartially, and typically did not expect or receive a large payout. ${ }^{212}$ Where payouts are low, it is difficult to incentivise unsecured creditors, although

\footnotetext{
${ }^{209}$ Ibid.

${ }^{210}$ Interview (n 7) (2 December 2014). The interviewee noted that the court clerks meet with the judges annually to decide collectively which trustees will be promoted or demoted in the List. The court clerks also play a large role in reviewing the activities of a trustee during a proceeding. Trustees will also often use the court clerks as a conduit when the trustees want to contact a judge.

${ }^{211}$ Ibid.

${ }^{212}$ Sakai et al. (n 5).
} 
junior creditors such as hedge funds and distressed debt investors may play a more active role in future and they are likely to demand more communication and information disclosure. ${ }^{213}$

Recent reforms in Australia, England, Singapore and China may also provide models for Japan's consideration, subject to adaption for Japan's circumstances. Australia's key industry body, the Australian Restructuring Insolvency \& Turnaround Association ("ARITA"), has required members to comply with its guidance on providing fee estimates, charging and explaining fees for some time, and provides seminars on its guidelines. It may take disciplinary action for noncompliance. ${ }^{214}$ The ARITA guidance was cited with approval in recent reform efforts in England and judicial commentary in Singapore. ${ }^{215}$ The JFBA's fee schedule was abolished in 2004, but is seemingly still used by practitioners and judges as a benchmark over a decade later. Whilst this type of guidance was abolished for being too prescriptive and anti-competitive, the ARITA feeestimate approach may at least provide a formal mechanism for guiding debtors, creditors and practitioners of what may reasonably be expected.

Moreover, Chinese courts in developed areas such as Shenzhen City and Zhejiang Province provide detailed guidance on fees to practitioners and their lists of qualified practitioners are publicly available. Shenzhen, for example, lists 22 law firms, three accounting firms and four liquidation companies as registered administrators. ${ }^{216}$ Whilst these developments aren't without their domestic critics, some consideration of these international examples could form part of a new framework for remunerating practitioners and even the appointment of practitioners. The JFBA may be the logical organisation to pursue reform in the first instance in light of its regulatory oversight of bengoshi who typically act as trustees and supervisors. As the case studies in this article suggest, however, the courts have also been an important drivers for change in this area.

\section{Conclusion}

The developments and case studies analysed in this article suggest that the existing system has served Japan well in terms of developing qualified practitioners who can handle many routine

\footnotetext{
${ }^{213}$ Ayotte and Morrison (n 209) 4-5, noting that junior lender activism has increased in the United States. Sonoo (n 26) 16 argues domestic creditors are also less likely to demand information in Japan because they are often related to the debtor or have long-standing relationships which means they have access to a lot of information already.

${ }^{214}$ Australian Restructuring Insolvency \& Turnaround Association, Code of Professional Practice (3rd edition) (1 January 2014), available at: <http://www.arita.com.au/about-us/publications/code-of-professional-practice> .

${ }^{215}$ Michael Murray, 'Practitioners Remuneration - UK Report Picks Up Ideas from IPA Code' (ARITA, 16 July 2013), available at: <www.arita.com.au/in-practice/insolvency-law-reform/corporate-insolvency-lawreform/2013/07/15/practitioners-remuneration---uk-report-picks-up-ideas-from-ipa-code>. See Justice Steven Chong's comments in See Kai Chai-Chau Linda v Fong Wai Lyn Carolyn (2015) SGJC 260.

${ }^{216}$ See Shenzhen Intermediate People's Court, available at: <http://ssfw.szcourt.gov.cn/frontend/pochangongkai/column/71/information/612>.
} 
cases for a reasonable fee. Accordingly, contemporary Japanese insolvency law history may provide useful regulatory and organisational perspectives for countries currently developing their own insolvency law framework and infrastructure. In future, however, Japan may need to move towards a more rules-based regulatory model for appointing and remunerating insolvency practitioners.

Despite acquiescence from bar associations in relation to new and cheaper schedules in the early 2000s, practitioners today are seeking to diversify their work and compete for better-paid work which may include pre-petition and informal appointments. ${ }^{217}$ These appointments potentially challenge the court's capacity to control remuneration, but there are ways that the courts can continue to exert influence. As in the 2010 case analysed in this article, the court-appointed trustee and court itself may have an opportunity to review remuneration if a case ultimately proceeds to a formal filing. Further, although pre-petition insolvency practitioners are not appointed from the court-verified Lists, the court still has the ultimate sanction of removing an insolvency practitioner from a List, thus excluding them from an important source of other work.

Legal and court reforms, together with domestic and international pressures, will continue to force further changes to Japanese courts' roles in appointing and remunerating insolvency practitioners. The pace of change, however, may not be as dramatic as the transformation achieved at the turn of the Century when a sense of urgency amongst the industry and courts facilitated the up-scaling and internal codification of the Tokyo District Court's approach to appointing insolvency practitioners and lowering of scheduled fees. The Tokyo District Court's innovations in relation to appointing and remunerating insolvency practitioners during this period suggest the influence that a judicial institution and its leadership can have on developing an insolvency profession. During this period, however, other developments were occurring which also enabled the Court to take these steps. The bar associations were eager to support new sources of work for bengoshi, and the increase in filings suggested a new area of practice for many bengoshi. Moreover, academics, bureaucrats, other judges and business people were working towards an overhaul of the legislative basis for insolvency proceedings in Japan. The difficult economic climate also made the reforms of the 21 st century possible. Calls for greater transparency will continue, however, especially if fewer cases and more bengoshi mean that many candidates for insolvency practitioner work miss out, or creditors become more assertive.

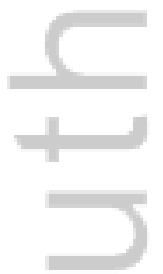

${ }^{217}$ As evidenced by the creation of the Japanese Association of Turnaround Professionals (JATP). On private ADR and insolvency, see Steele and Chun (n 16) para 19-645. 


\section{University Library}

\section{- M M N E R VA A gateway to Melbourne's research publications}

Minerva Access is the Institutional Repository of The University of Melbourne

Author/s:

Steele, S

Title:

Appointing and Remunerating Insolvency Practitioners in Japan: The Roles of Japanese Courts

Date:

2017-03-01

Citation:

Steele, S. (2017). Appointing and Remunerating Insolvency Practitioners in Japan: The Roles of Japanese Courts. INTERNATIONAL INSOLVENCY REVIEW, 26 (1), pp.82-118. https://doi.org/10.1002/iir.1270.

Persistent Link:

http://hdl.handle.net/11343/292560 